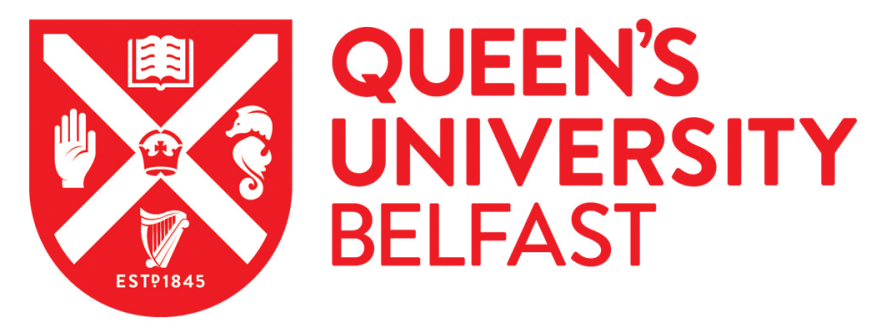

\title{
Electrical Resistance Tomography for Gas Holdup in a Gas-Liquid Stirred Tank Reactor
}

Sardeshpande, M. V., Gupta, S., \& Ranade, V. V. (2017). Electrical Resistance Tomography for Gas Holdup in a Gas-Liquid Stirred Tank Reactor. Chemical Engineering Science. https://doi.org/10.1016/j.ces.2017.04.025

\author{
Published in: \\ Chemical Engineering Science
}

Document Version:

Peer reviewed version

Queen's University Belfast - Research Portal:

Link to publication record in Queen's University Belfast Research Portal

Publisher rights

(c) 2017 Elsevier Ltd. This manuscript version is made available under the CC-BY-NC-ND 4.0 license http://creativecommons.org/licenses/by$\mathrm{nc}-\mathrm{nd} / 4.0 /$,which permits distribution and reproduction for non-commercial purposes, provided the author and source are cited.

\section{General rights}

Copyright for the publications made accessible via the Queen's University Belfast Research Portal is retained by the author(s) and / or other copyright owners and it is a condition of accessing these publications that users recognise and abide by the legal requirements associated with these rights.

Take down policy

The Research Portal is Queen's institutional repository that provides access to Queen's research output. Every effort has been made to ensure that content in the Research Portal does not infringe any person's rights, or applicable UK laws. If you discover content in the Research Portal that you believe breaches copyright or violates any law, please contact openaccess@qub.ac.uk. 
Electrical Resistance Tomography for Gas Holdup in a Gas-Liquid Stirred Tank Reactor

Madhavi V. Sardeshpandea, Suraj Gupta ${ }^{\mathrm{b}}$ and Vivek V. Ranade ${ }^{\mathrm{a}^{*}}$

alndustrial Flow modeling group, National Chemical Laboratory, Pune - 411008

${ }^{\mathrm{b}}$ Chemical Engineering Department, Visvesvaraya National Institute of Technology Nagpur 440010

* Current address: School of Chemistry and Chemical Engineering, Queen's University Belfast, Belfast BT9 5 AG, UK (V.Ranade@qub.ac.uk)

Email: $\underline{\text { mv.sardeshpande@ncl.res.in }}$ 


\section{Abstract:}

Gas-Liquid flows in stirred tank reactors (STR) are used in many significant industrial operations such as hydrogenation, absorption, stripping, oxidation, hydrogenation, ozonation, chlorination, fermentation, etc. Gas-Liquid STRs are expected to perform several functions such as mixing, dispersing gas into liquid, mass and heat transfer and reactions. Gas hold up distribution and various flow regimes are the key parameters affecting performance of gas-liquid STRs. Various techniques such as visual analysis, photography, light attenuation, optical probe method are used to understand gas hold-up distribution within stirred tanks. Most of these techniques have some limitations with respect to measurement of gas hold up distribution. Electrical Resistance Tomography (ERT) is an upcoming technique for obtaining both qualitative and quantitative data on multiphase process units non-invasively and non-intrusively. In this work, an attempt was made to establish and validate the ERT technique for characterizing gas-liquid flows in a laboratory scale STR using the Rushton turbine (RT) impeller. ERT was used to study gas holdup and to identify flow regimes. The results were compared with the visual measurements as well as previously published correlations. The effect of gas flow rate, impeller speed on the mean gas holdup is discussed. The methodology and results presented in this work will be useful to effectively apply ERT for characterizing gas-liquid flows in stirred tanks.

Keywords: Gas-liquid system, Gas Holdup, Flow Regime, ERT 


\section{Introduction}

Gas-Liquid flows in stirred tank reactors (STR) have many industrial applications such as absorption, stripping, oxidation, hydrogenation, ozonation, chlorination, fermentation, etc. STRs are mostly used for mixing, effectively dispersing dispersed phase into continuous phase, realizing desired mass and heat transfer for carrying out various industrially relevant transformations. Despite the widespread use of stirred vessels, variations in design, operational protocols and complexities of multiphase system always pose challenges for improving reactor performance.

Gas holdup and flow regimes are key parameters for performance estimation and scaling up of reactors. Gas-Holdup or void fraction is defined as the volume occupied by gas bubbles as a fraction of the clear liquid volume and is one of the measures of the efficiency of gasliquid contacting. It is one of the most important characteristics needed to understand; design and model gas-liquid flows for allowing rational design and scale up of the reactors (Dong et al., 2003, Dong et al., 2012, Paglianti et al., 2000) . Therefore, it is an important parameter studied widely by many researchers (Dong et al., 2012, Dave et al., 2009, J in et al., 2013, Karimi et al., 2013) (see Table 1a and Table 1b).

Concerning the measurement of gas-liquid flows in stirred tank reactor; various techniques have been used in the past (see Table 2) such as visual analysis, photography, light attenuation, optical probe methods etc. However to understand the dynamics of the process it is very imperative to have the capacity to visualize inside the process. In process industries, most of the systems are opaque systems which eliminate the usefulness of many techniques in the real investigations. According to the industrial application, it is very important to have a measuring technique that can give the information of the process without disturbing the flow. Electrical resistance tomography (ERT) is one such technique gaining the popularity in this domain due to its unmatched potential of providing both 
qualitative and quantitative information on the internal investigated space and behavior of process flows without causing any disturbance.

Recently our group has demonstrated the applicability of ERT technique for liquid phase mixing in solid-liquid stirred tank reactor (Sardeshpande et al., 2016). The present work is focused on extending ERT technique for identification of gas-liquid flow regimes and gas hold up distribution inside the tank. Qualitative and quantitative data was compared with conventional techniques and correlations (reported in Table 3). Effect of impeller speed and superficial gas velocity on gas holdup was studied and flow regime identification was done using the raw conductivity data extracted from the ERT system.

Applying the finding of this study will lead to improved guidelines for efficient use of stirred reactors. ERT technique provides the required information to experimentalist to evaluate this technology effectively in opaque system. Literature review, overall methodology of work, results and discussions are presented in following section.

\section{Brief Review of Literature}

Among various conventional techniques visual method is a quick and basic technique to measure the gas holdup and identify the flow regimes. This is therefore one of the most commonly used techniques for characterizing gas-liquid flows in stirred tanks. However, it has obvious limitation of a transparent system. For higher values of gas hold-up, the system no longer remains transparent even of the vessel is transparent. Converting the images into quantitative data also has its own challenges.

Gamma ray and $X$ ray absorption radiography is a measurement of the attenuation of radiations due to the two phase mixture present in the reactor that gives the local mass density along the radiation path. This technique works on the principle of different 
absorption coefficients of different phases towards different radiations. Radiography techniques are limited by safety and high price issues.

X-ray tomography is an imaging technique based upon the attenuation measurement of photon rays. The images obtained from this technique give the information about the density of each pixel and the phase fraction. 2D Fast Fourier transformation is used as the reconstruction algorithm to reconstruct the images. This technique is a non-invasive and industrially used technique but requires high power and is expensive.

Many needle probe methods are also available to study the aspects of a gas-liquid systems such as optical probes, conductivity probes etc. In probe method, a sharp thin probe is set in a reactor to face flow direction in order to get in touch with as many bubbles as possible. In optical needle probe, an analog signal is produced using an opto-electronic device. The needle is dipped in the mixture and an infrared light is charged to the tip. This tip in return transmits light beam when in contact with liquid medium or else reflects it back to the device when is in contact with gas. In conductivity probes, a probe is dipped into the system to measure the conductivity of the fluid phases. This technique measures the variation of conductivity of the system due to the presence of another phase that is used to find the gas phase fraction using different proposed correlations. Probe methods are generally used to study high gas holdup systems and are very useful in providing complete hydrodynamic characteristics of the system and also pose several limitations. Some of them are requirement of very thin needle, invasiveness, errors in measurement due to turbulences, probe orientation etc.

Thus limitations of conventional techniques restrict applicability of these techniques at larger scales. In this work we apply and evaluate ERT for characterizing gas-liquid flows in STR. 
ERT can non-intrusively investigate flow processes inside vessels with adequate spatiotemporal resolution. It is generally used to interrogate and monitor the process where the main continuous phase is slightly conducting and the other phases have different values of conductivity. Its robustness, fast data acquisition, inexpensive material cost, easy installation, no radiation hazard, non-intrinsic and non-intrusive nature makes it more attractive than other conventional techniques (Wang et al., 2013, Rodgers et al., 2010, Zhang et al., 2012, Abdullah et al., 2009, Takriff et al., 2013, Fransolet et al., 2005).

ERT provides real time cross sectional images of conductivity distribution within its sensing region. Parameters such as gas-holdups and radial profiles can be extracted from the reconstructed images. ERT combined with a simple linear back projection algorithm for the reconstruction of images can be used to obtain real time online measurements. ERT showed its applicability for gas holdup measurement, flow regime identification, biomedical application, velocity profile (Aw et al., 2014, Takriff et al., 2009, Pinheiro et al., 1998, Abdullah et al., 2011, J in et al., 2007) etc.

It is evident that ERT could prove a useful measuring technique to understand dynamics of gas-liquid flows in a STR as compared to conventional techniques. An attempt is made here to establish and validate the ERT technique for characterizing gas-liquid flow in a laboratory scale STR. 
Table 1a: Literature Review on Gas Holdup determination by different techniques

\begin{tabular}{|c|c|c|c|c|c|c|c|}
\hline Reference & $\begin{array}{l}\text { Design } \\
\text { Conditions }\end{array}$ & $\begin{array}{l}\text { Sparger } \\
\text { and } \\
\text { baffles }\end{array}$ & Impeller & $\begin{array}{l}\text { Operating } \\
\text { conditions }\end{array}$ & Technique & $\begin{array}{l}\text { Studied } \\
\text { Parameters }\end{array}$ & Remarks \\
\hline $\begin{array}{l}\text { Dudukovic } \\
\text { et. Al } \\
(2010)\end{array}$ & $\begin{array}{l}T-20 \mathrm{~cm} \\
C / T-0.33 \\
D / T-0.33 \\
H / T-1\end{array}$ & $\begin{array}{l}\text { Ring } \\
\text { Baffles } \\
-2\end{array}$ & 6RT & $\begin{array}{l}\text { N- 350-750 rpm } \\
\text { Q- 264-750 I/h } \\
\text { Air-Water }\end{array}$ & $\begin{array}{l}\text { Optical } \\
\text { Probe }\end{array}$ & Gas Holdup & $\begin{array}{l}\text { Lack of } \\
\text { quantitative } \\
\text { information/ data }\end{array}$ \\
\hline $\begin{array}{l}\text { Dudukovic } \\
\text { et al., } \\
(2014)\end{array}$ & $\begin{array}{l}T-20 \mathrm{~cm} \\
C / T-0.33 \\
D / T-0.33 \\
H / T-1\end{array}$ & $\begin{array}{l}\text { Ring } \\
\text { Baffles } \\
-4\end{array}$ & $6 \mathrm{RT}$ & $\begin{array}{l}\text { N- } 126-830 \mathrm{rpm} \\
\text { Q- 58-850 l/h } \\
\text { Air-Water }\end{array}$ & $\begin{array}{l}\text { Optical } \\
\text { Probe }\end{array}$ & $\begin{array}{l}\text { Gas Holdup \& } \\
\text { Bubble count at } \\
\text { different } \\
\text { locations }\end{array}$ & $\begin{array}{l}\text { Identification of } \\
\text { regimes }\end{array}$ \\
\hline $\begin{array}{l}\text { Chandram } \\
\text { ohan et } \\
\text { al., (2009) }\end{array}$ & $\begin{array}{l}T-45 \mathrm{~cm} \\
C / T-0.33 \\
D / T-0.33 \\
H / T-2\end{array}$ & $\begin{array}{l}\text { Ring } \\
\text { Baffles } \\
-4\end{array}$ & $\begin{array}{l}\text { PTD, } \\
\text { PTU, DT }\end{array}$ & $\begin{array}{l}\text { N- 150-1200 rpm } \\
\text { Q- 2880-5760 l/h } \\
\text { Air-Water }\end{array}$ & $\begin{array}{l}\text { Visual } \\
\text { Method }\end{array}$ & $\begin{array}{l}\text { Effect of } \\
\mathrm{C} / \mathrm{T} \text {, inter- } \\
\text { impeller } \\
\text { clearance and } \\
\text { surface tension } \\
\text { on } \varepsilon_{\mathrm{g}} \text { for the } \\
\text { optimum C/T }\end{array}$ & $\begin{array}{l}\text { Bottom clearance } \\
\text { of } T / 3 \text { gave the } \\
\text { maximum gas } \\
\text { holdup }\end{array}$ \\
\hline $\begin{array}{l}\text { Takriff et. } \\
\text { al., (2013) }\end{array}$ & $\begin{array}{l}T-40 \mathrm{~cm} \\
C / T-0.33 \\
D / T-0.33 \\
H / T-1.4\end{array}$ & $\begin{array}{l}\text { Nozzle } \\
\text { Sparger } \\
\text { Baffles } \\
-4\end{array}$ & $\begin{array}{l}\text { RT, } \\
\text { Lightnin } \\
\text { A320 }\end{array}$ & $\begin{array}{l}\text { N- 0-400 rpm } \\
\text { Q- 120-480 l/h } \\
\text { Air-Water }\end{array}$ & ERT & \begin{tabular}{l}
\multicolumn{2}{c}{ Gas Holdup and } \\
Mass transfer \\
coefficient were \\
measured for \\
different \\
impellers
\end{tabular} & $\begin{array}{l}\text { ERT used to } \\
\text { determine the } \\
\text { optimum } \\
\text { conditions for } \\
\text { gas-liquid mixing }\end{array}$ \\
\hline $\begin{array}{l}\text { Yawalkar } \\
\text { et al., } \\
(2002)\end{array}$ & $\begin{array}{l}\mathrm{T}-57 \mathrm{~cm} \\
\mathrm{C} / \mathrm{T}-0.33 \\
\mathrm{D} / \mathrm{T}-0.33 \\
0.5 \mathrm{H} / \mathrm{T}-1\end{array}$ & $\begin{array}{l}\text { Perfora } \\
\text { ted } \\
\text { Pipe } \\
\text { Baffles } \\
-4 \\
\end{array}$ & DT, PTD & $\begin{array}{l}\text { N- 108-1080 rpm } \\
\text { Air-Water }\end{array}$ & $\begin{array}{l}\text { Visual } \\
\text { Method }\end{array}$ & Gas Holdup & $\begin{array}{l}\varepsilon_{g} \text { depends on } \\
\text { various } \\
\text { correlations. } \\
\text { Difficult to predict }\end{array}$ \\
\hline
\end{tabular}


Table 2b: Literature Review on Gas Holdup determination by different techniques

\begin{tabular}{|c|c|c|c|c|c|c|c|}
\hline Reference & $\begin{array}{l}\text { Design } \\
\text { Conditions }\end{array}$ & $\begin{array}{l}\text { Sparger } \\
\text { and } \\
\text { baffles }\end{array}$ & Impeller & $\begin{array}{l}\text { Operating } \\
\text { conditions }\end{array}$ & Technique & $\begin{array}{l}\text { Studied } \\
\text { Parameters }\end{array}$ & Remarks \\
\hline $\begin{array}{l}\text { Takriff et. } \\
\text { Al (2009) }\end{array}$ & $\begin{array}{l}T-40 \mathrm{~cm} \\
C / T-0.33 \\
D / T-0.33 \\
H / T-1.4\end{array}$ & $\begin{array}{l}\text { Nozzle } \\
\text { Sparger } \\
\text { Baffles } \\
-4\end{array}$ & 8DT & $\begin{array}{l}\text { N- 0-400 rpm } \\
\text { Q- 120-480 I/h } \\
\text { Air-Water }\end{array}$ & ERT & Gas holdup & $\begin{array}{l}\text { Transitional flow } \\
\text { pattern were } \\
\text { studied using } \\
\text { surface plots and } \\
\text { Axial profiles. }\end{array}$ \\
\hline $\begin{array}{l}\text { Karimi } \\
\text { etal., } \\
\text { (2013) }\end{array}$ & $\begin{array}{l}T-10 \mathrm{~cm} \\
C / T-0.5 \\
D / T-0.5 \\
H / T-3\end{array}$ & $\begin{array}{l}\text { Orifice } \\
\text { Baffles } \\
-4\end{array}$ & $\begin{array}{l}\text { RT, P4B- } \\
\text { D, P2B- } \\
\text { D }\end{array}$ & $\begin{array}{l}\text { N- 100-1000 rpm } \\
\text { Q- 60-300 l/h } \\
\text { Air-Water }\end{array}$ & Visual & $\begin{array}{l}\text { Gas Holdup } \\
\text { with resepect to } \\
\text { flow rate and } \mathrm{N}\end{array}$ & $\begin{array}{l}\text { Identification of } \\
\text { Flow regimes }\end{array}$ \\
\hline $\begin{array}{l}\text { Huang et } \\
\text { al., (2012) }\end{array}$ & $\begin{array}{l}\text { T }-98 \mathrm{~cm} \\
C / T-0.33 \\
D / T-0.33 \\
H / T-1\end{array}$ & $\begin{array}{l}\text { Pipe } \\
\text { Baffles } \\
-2 \\
\text { Finger } \\
\text { type } \\
\text { baffle }\end{array}$ & 6-DT & $\begin{array}{l}\text { N- 50-200 rpm } \\
\text { Q- 39600-100800 } \\
\text { l/h } \\
\text { Air-Water }\end{array}$ & $\begin{array}{l}\text { Acoustic } \\
\text { Emission } \\
\text { Method }\end{array}$ & $\begin{array}{l}\text { Flow regime } \\
\text { identification }\end{array}$ & $\begin{array}{l}\text { Understanding on } \\
\text { flow regimes and } \\
\text { transition. }\end{array}$ \\
\hline $\begin{array}{l}\text { Kulkarni et } \\
\text { al (2011) }\end{array}$ & $\begin{array}{l}T-30 \mathrm{~cm} \\
C / T-0.33 \\
D / T-0.33 \\
H / T-1 \\
W=T / 10\end{array}$ & $\begin{array}{l}\text { Ring } \\
\text { Baffles } \\
-4\end{array}$ & $\begin{array}{l}\text { 6DT, } \\
\text { 6PBTD, } \\
\text { FI }\end{array}$ & $\begin{array}{l}\text { N- 0-250 rpm } \\
\text { Q- 500-2050 I/h } \\
\text { Air-Water }\end{array}$ & $\begin{array}{l}\text { Visual } \\
\text { Method }\end{array}$ & $\begin{array}{l}\text { Gas holdup at } \\
\text { different } \\
\text { superficial } \\
\text { velocities and } \\
\text { impeller speed. }\end{array}$ & $\begin{array}{l}\text { Established } \\
\text { qualitative data }\end{array}$ \\
\hline $\begin{array}{l}\text { Paglianti } \\
\text { et al., } \\
(2000)\end{array}$ & $\begin{array}{l}20, \quad \text { dished } \\
\text { bottom } \\
=0.5 \mathrm{~T} \\
\mathrm{C} / \mathrm{T}-0.33 \\
\mathrm{D} / \mathrm{T}-0.5 \\
\mathrm{H} / \mathrm{T}-1.75 \\
\mathrm{~W}=\mathrm{T} / 10\end{array}$ & $\begin{array}{l}\text { Porous } \\
\text { sintere } \\
\text { d plate } \\
\text { Baffles } \\
-4\end{array}$ & RT & $\begin{array}{l}\text { N- 250-400 rpm } \\
\text { Q- 100- } 1100 \mathrm{l} / \mathrm{h} \\
\text { Air-Water }\end{array}$ & $\begin{array}{l}\text { Conductanc } \\
\text { e Probe }\end{array}$ & $\begin{array}{l}\text { Time series } \\
\text { analysis for flow } \\
\text { regime } \\
\text { identification. }\end{array}$ & $\begin{array}{l}\text { Time series data } \\
\text { from the } \\
\text { conductance } \\
\text { probe is given for } \\
\text { different regimes. } \\
\text { Can be used as } \\
\text { reference. }\end{array}$ \\
\hline
\end{tabular}


Table 3: Review on Different Techniques

\begin{tabular}{|c|c|c|c|}
\hline Technique & Principle & $\begin{array}{l}\text { Expected } \\
\text { Results }\end{array}$ & Limitations \\
\hline $\begin{array}{l}\text { Optical Probe } \\
\text { Method (Lee and } \\
\text { Dudukovic 2014, } \\
\text { Fordham 1999a-b- } \\
\text { c, Guet et al., 2003, } \\
\text { Julia et al., 2005) }\end{array}$ & $\begin{array}{l}\text { Infrared light beam is send to } \\
\text { the tip of the probe. } \\
\text { Light beam gets transmitted in } \\
\text { the liquid region whereas } \\
\text { reflects back to the device in } \\
\text { the presence of gaseous } \\
\text { medium. } \\
\text { Optoelectronic device used } \\
\text { gives an analog output signal } \\
\text { proportionate to the received } \\
\text { light intensity. }\end{array}$ & $\begin{array}{l}\text { Gas Holdup, } \\
\text { Bubble } \\
\text { Velocity }\end{array}$ & $\begin{array}{l}\text { Invasive, difficult to } \\
\text { use near vicinity of } \\
\text { reactor wall, multiple } \\
\text { tip probe requires } \\
\text { reconstruction } \\
\text { model. }\end{array}$ \\
\hline Light Attenuation & $\begin{array}{l}\text { Works on the principle of } \\
\text { radiation attenuation when } \\
\text { passed through two phase } \\
\text { mixture. In this technique, } \\
\text { light is passed and attenuation } \\
\text { is recorded as the function of } \\
\text { specific interfacial area of the } \\
\text { dispersed phase. }\end{array}$ & $\begin{array}{l}\text { Gas holdup } \\
\text { and } \\
\text { interfacial } \\
\text { area }\end{array}$ & $\begin{array}{l}\text { Transparent vessel } \\
\text { and liquid are } \\
\text { required, prone to } \\
\text { electronic noise, } \\
\text { parasitic light source. }\end{array}$ \\
\hline $\begin{array}{l}\text { Photography and } \\
\text { Image analysis } \\
\text { (Khopkar et al., } \\
\text { 2005, Wang et al., } \\
\text { 2006) }\end{array}$ & $\begin{array}{l}\text { In this photographs are taken } \\
\text { and results are reported on } \\
\text { the basis of image analysis } \\
\text { using different post processing } \\
\text { software such as Image J, } \\
\text { Image Pro-Plus, Proanalyst }\end{array}$ & $\begin{array}{l}\text { Flow Regime } \\
\text { Bubble/drop } \\
\text { size shape }\end{array}$ & $\begin{array}{l}\text { Transparent vessel } \\
\text { and liquid required, } \\
\text { quantitative image } \\
\text { analysis not always } \\
\text { possible. }\end{array}$ \\
\hline $\begin{array}{l}\text { Gamma \& } \\
\text { X ray } \\
\text { Technique (Veera } \\
\text { et al., 2001, Ford et } \\
\text { al., 2008, Hampel } \\
\text { et al., 2007) }\end{array}$ & $\begin{array}{l}\text { Gamma and } X \text { ray radiations } \\
\text { are used to produce the } \\
\text { tomographs and phase } \\
\text { dispersion. }\end{array}$ & $\begin{array}{l}\text { Phase holdup } \\
\text { distribution }\end{array}$ & $\begin{array}{l}\text { Expensive and high } \\
\text { power required }\end{array}$ \\
\hline $\begin{array}{l}\text { Ultrasonic } \\
\text { Tomography (Cents } \\
\text { et al., 2005) }\end{array}$ & $\begin{array}{l}\text { Tomographs are produced } \\
\text { using Ultrasonic waves. } \\
\text { Ultrasonic wave propagation } \\
\text { depends on both the phase } \\
\text { fraction and on the phase } \\
\text { configuration (flow regime, } \\
\text { size of dispersed particles). }\end{array}$ & $\begin{array}{l}\text { Phase holdup } \\
\text { distribution }\end{array}$ & $\begin{array}{l}\text { Low solid and gas } \\
\text { holdup }(<20 \%)\end{array}$ \\
\hline
\end{tabular}


Table 4: Various Gas Holdup Correlations

\begin{tabular}{|l|l|l|}
\hline Reference & Correlation & $\begin{array}{l}\text { System } \\
\text { Specification }\end{array}$ \\
\hline $\begin{array}{l}\text { Greaves and Barigou } \\
\text { (1990) }\end{array}$ & $\varepsilon_{g}=4.07 \mathrm{~N}^{0.62} \mathrm{Q}^{0.64}\left(\frac{\mathrm{D}}{\mathrm{T}}\right)^{1.39}$ & $\mathrm{~T}=1$ \\
\hline $\begin{array}{l}\text { Greaves and Barigou } \\
\text { (1990) }\end{array}$ & $\varepsilon_{\mathrm{g}}=4.2 \mathrm{~N}^{0.79} \mathrm{Q}^{0.52}\left(\frac{\mathrm{D}}{\mathrm{T}}\right)^{1.92}$ & $\mathrm{~T}=1$ \\
\hline $\begin{array}{l}\text { Smith (1991) } \\
\text { Rewatkar et al., } \\
\text { (1993) }\end{array}$ & $\varepsilon_{\mathrm{g}}=3.54 \mathrm{Fl} \mathrm{I}^{0.43} \mathrm{Fr}^{0.51}\left(\frac{\mathrm{D}}{\mathrm{T}}\right)^{2.08}$ & $\mathrm{~T}>0.44$ \\
\hline $\begin{array}{l}\text { Yawalkar et al } \\
\text { (2002) }\end{array}$ & $\varepsilon_{\mathrm{g}}=0.122\left(\frac{\mathrm{N}}{\mathrm{Ncd}}\right)^{0.64} \mathrm{vvm}^{0.69} \mathrm{~T}^{0.32}\left(\frac{\mathrm{D}}{\mathrm{T}}\right)^{0.14}$ & $\mathrm{~T}>1$ \\
\hline $\begin{array}{l}\text { Hassan et al., (1977) } \\
\text { and Foster }\end{array}$ & $\left.\varepsilon_{\mathrm{g}}=0.209\left(\frac{\mathrm{DN}}{\mathrm{T}}\right)^{1.25}\right)^{0.44}$ & $\mathrm{~T}>0.57$ \\
\hline $\begin{array}{l}\text { Lee } \\
\text { (1990) }\end{array}$ & $\varepsilon_{\mathrm{g}}=4.2\left(\frac{\mathrm{N}}{\mathrm{Ncd}}\right)^{1.33} \mathrm{vvm}^{1.3}$ & $\mathrm{~T}>0.29$ \\
\hline
\end{tabular}

Gas Holdup in a Gas-liquid STR

In a gas-liquid flow, majorly three regimes have been reported in literature i.e. flooding, loading and fully re-circulated regimes (Figure $1 \mathrm{a}$ and Figure $1 \mathrm{~b}$ ). These regimes are described by two dimensionless numbers i.e. Flow Number (FI) and Froude Number (Fr). The Fl number is the ratio between the gas flow rate and the impeller driven flow rate and the Fr number is the ratio between the impeller driven acceleration and gravity

$$
\begin{aligned}
& F l=\frac{Q}{N \times D^{3}} \\
& F r=\frac{D \times N^{2}}{g}
\end{aligned}
$$




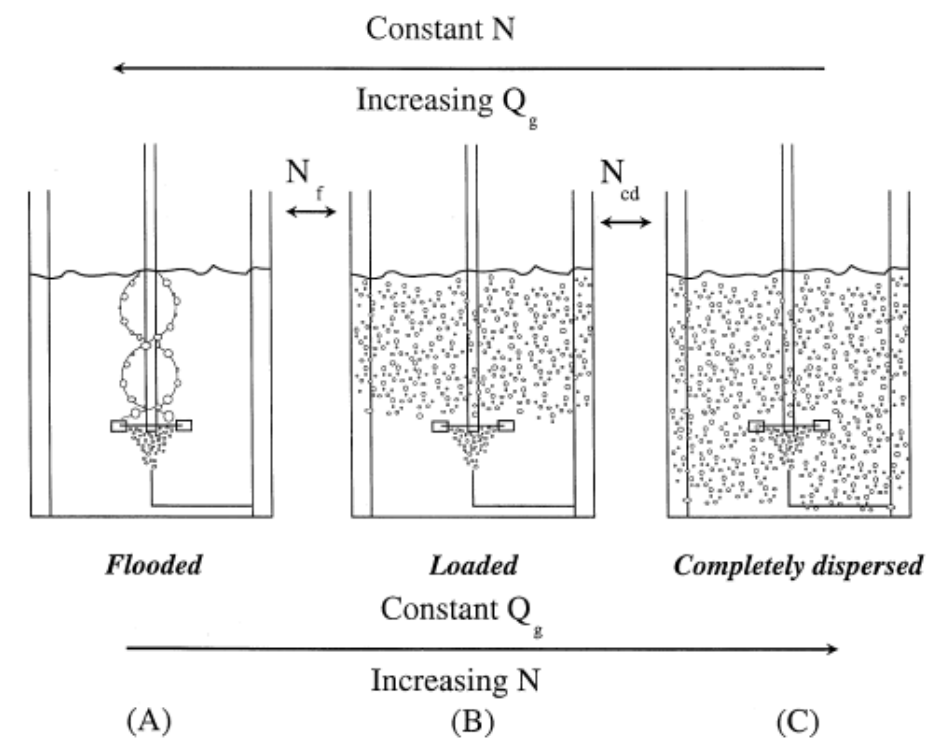

Figure 1a: Schematic representation of the bulk flow patterns: (A) flooded, (B) Loading, (C) Completely Dispersed (Nienow et al., 1985)

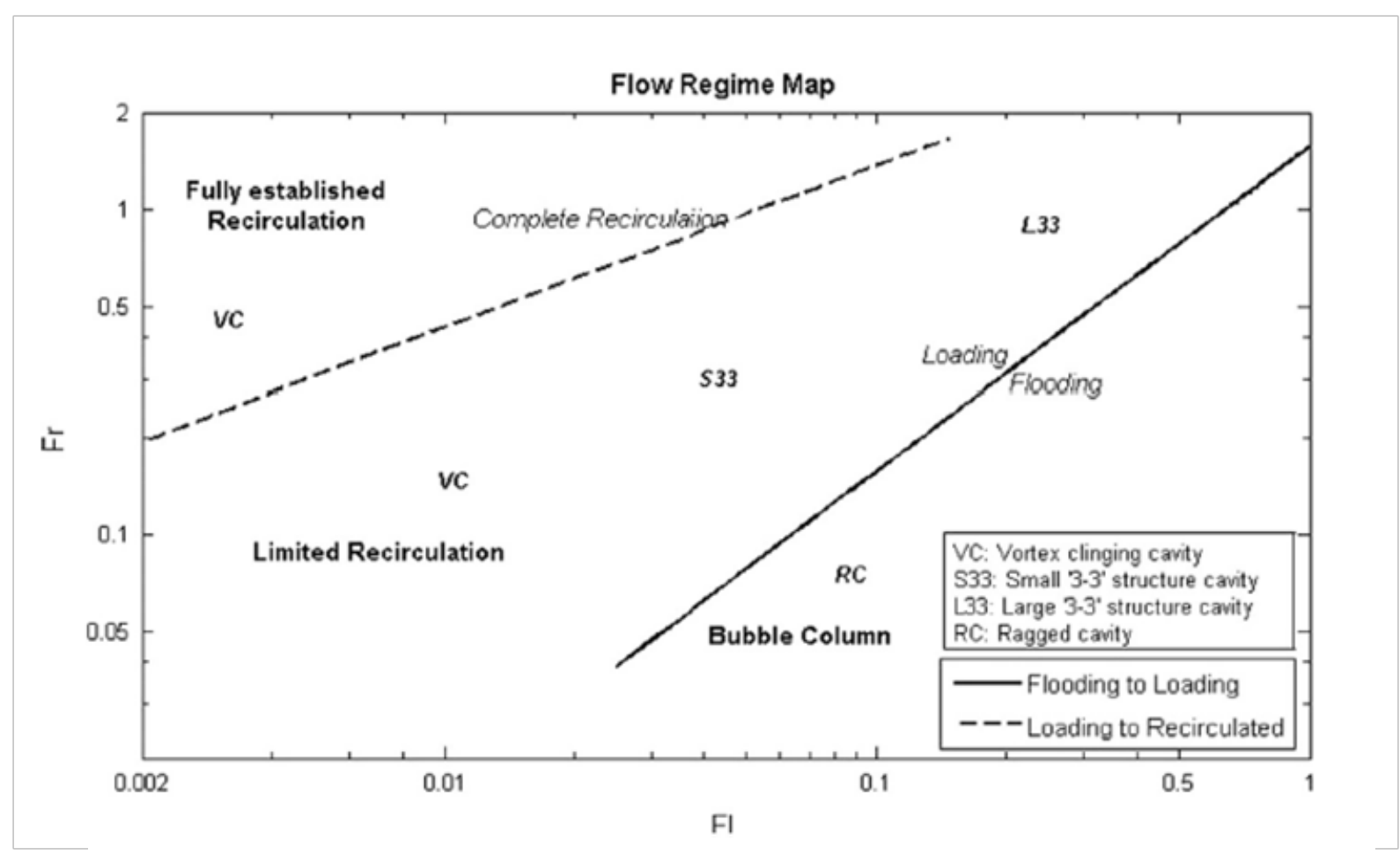

Figure 1b: Complete flow regime map for a standard fully baffled air-water STR (Lee and Dudukovic 2014) 


\section{Experimental facility}

A cylindrical stirred vessel fitted with 4 bladed Rushton Turbine (RT) was used for gas-liquid experiments as shown in Figure 2a. Rushton turbine is a radial flow impeller, has been acknowledged in industry as a viable impeller for gas-liquid mixing. The diameter of the vessel and liquid height was $0.2 \mathrm{~m}$ whereas diameter of the impeller was $0.08 \mathrm{~m}$. Three baffles having width $0.02 \mathrm{~m}$ (i.e. T/10) were selected and installed in the tank. The vessel was equipped with an ITS Z8000 system. Two ERT planes of 16-sensor rings were mounted on the vessel wall (i.e. Plane -1 (below the impeller) and Plane -2 (above the impeller)); the vertical distance between neighboring electrodes was $0.04 \mathrm{~m}$. Water (i.e. continuous phase) was used as a working fluid whereas Nitrogen (i.e. dispersed phase) was fed into the tank through the ring sparger installed just underneath the impeller. Operating parameters such as impeller speed was $100 \mathrm{rpm}$ to $400 \mathrm{rpm}$ and the gas flow rate was $100 \mathrm{l} / \mathrm{h}$ to $400 \mathrm{l} / \mathrm{h}$. Sample photographs of gas dispersion formation with respect to impeller speed are as shown in Figure $2 b$.

Major parameters contemplated in this experiment are superficial gas velocities, impeller speed, gas Holdup distribution and flow regimes. As mentioned earlier, with current operating parameters and according to Flow and Froude number; flow regime map for the experimental range considered in the present study is as shown in Figure $2 \mathrm{c}$.

The ITS Z8000 ERT system is furnished with a real-time data acquisition system that has the capability to capture images at 45 frames/s. The gas dispersion images were reconstructed from the ERT measurements using Image reconstruction software i.e. ITS tool suite software installed on the host PC. The software used a simple non-iterative linear back projection algorithm (LBPA) for reconstruction of the images. 

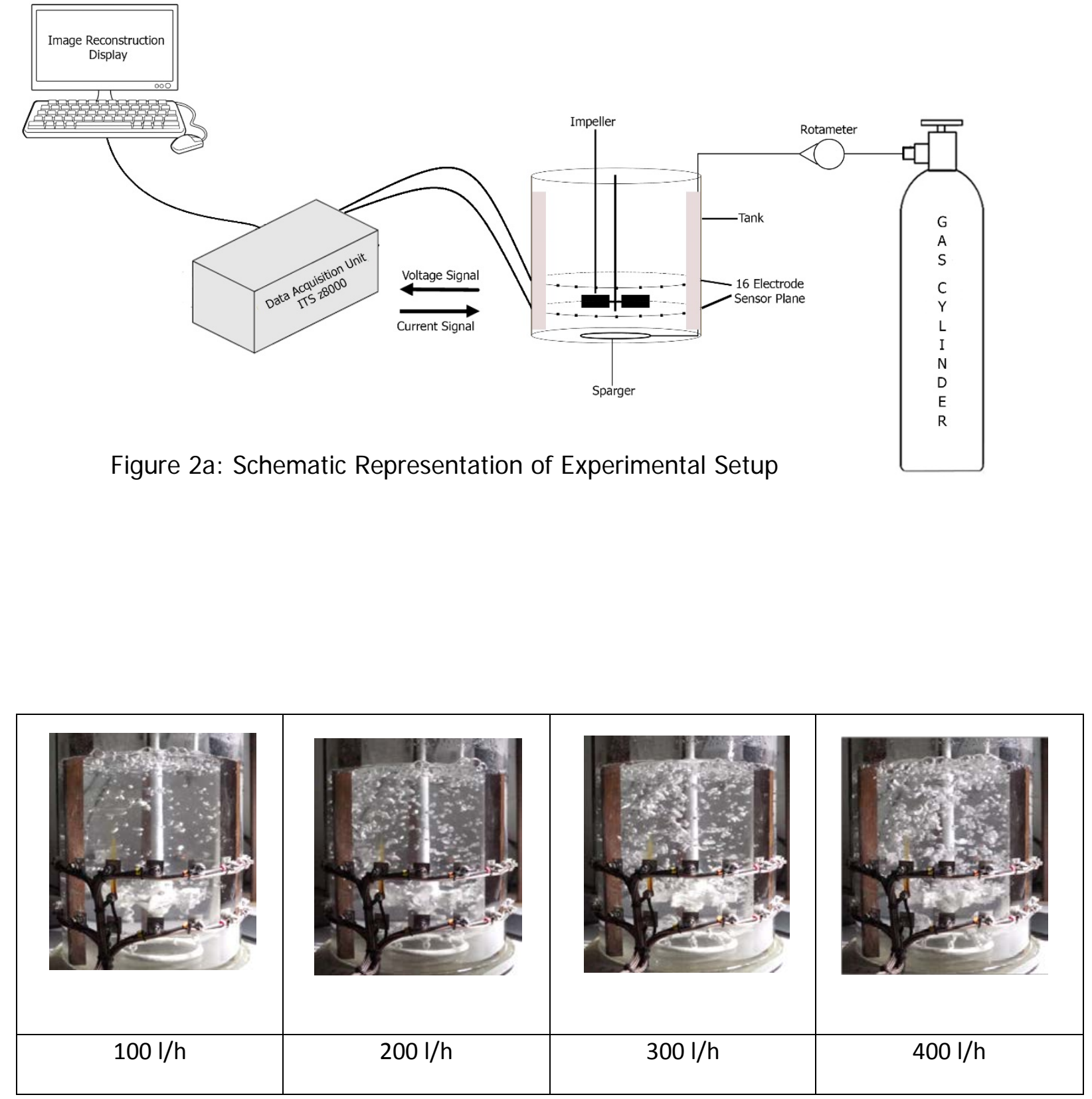

Figure 2b: Pictorial views of gas distribution at different gas flow rates at 200rpm 


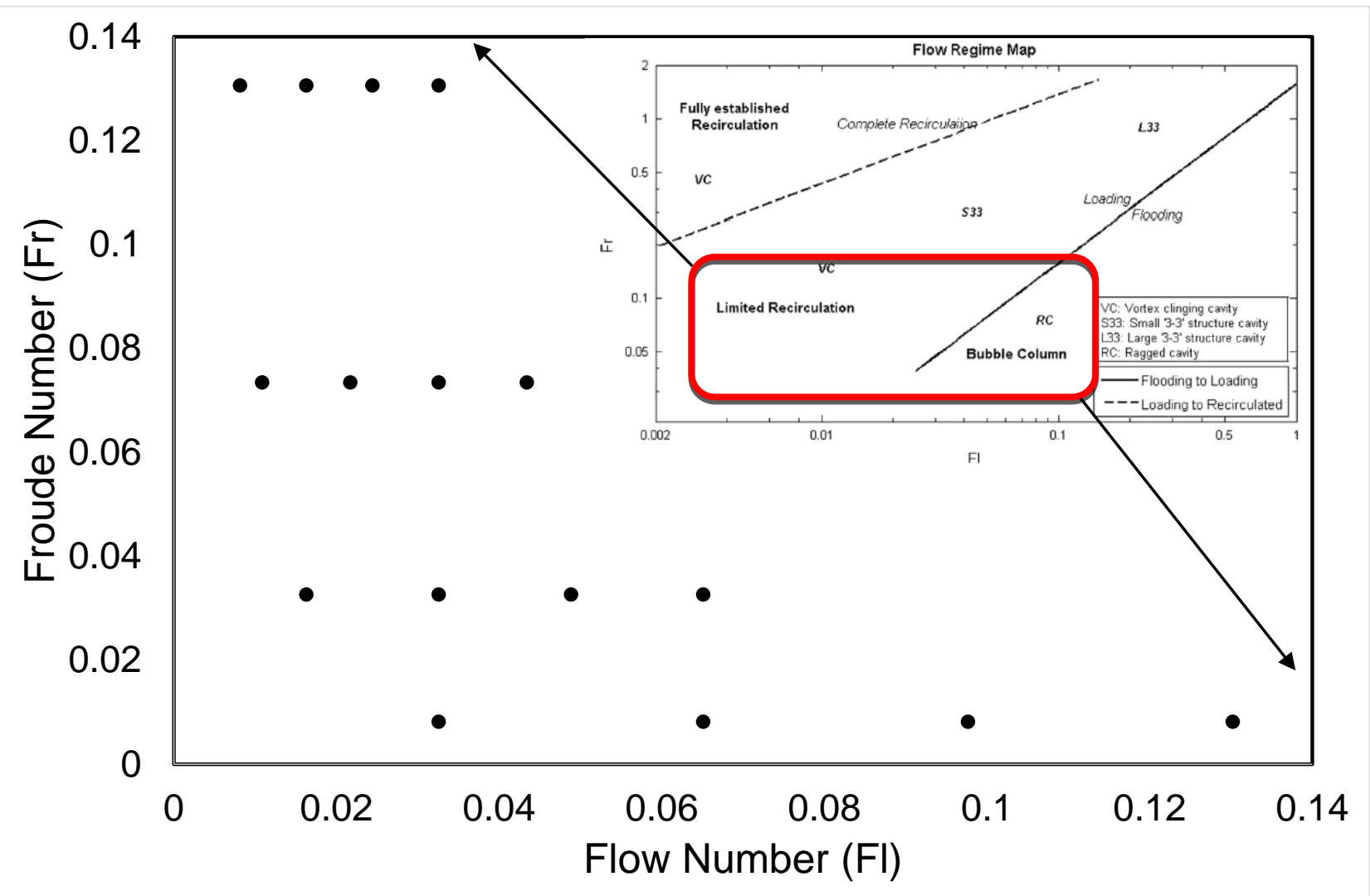

Figure 1c: Flow regime map for the experimental range considered in the present study 


\subsection{Electrical Resistance Tomography}

\section{Principle:}

ERT system measures resistance distribution in the area of concern. This is obtained by applying currents (or voltages) and measuring voltages (or currents) via electrodes mounted on the boundary of the domain. Normally, the electrodes, located around the boundary of the vessel, make electrical contact with the fluid inside the vessels and are connected to the data acquisition system (DAS) by co-axial cables to reduce the electromagnetic noise and interference (Dickin and Wang 1996).

ERT comprises of two major components such as (1) Hardware: sensors signal/data control and (2) Software: signal reconstruction, display and interpretation facilities, and generation of output control signals to process hardware.

The steps to extract desired information are completed in two stages, Image Processing and Process Imaging. Process Imaging or sensing systems is used to acquire the resistance distribution in the domain of interest. To provide the same, multiple equally axially spaced rings of electrodes are located around the vessel and each ring consists of 16 equally spaced rectangular stainless plates (electrodes) formed into a circular ring. To reduce the irrelevant environmental noise and interference, the electrodes are connected to the data acquisition system by co-axial cables. To ensure all voltage measurements are fixed against a common ground source, one ground electrode is used.

The data on conductivity distribution is acquired using data acquisition system (DAS). DASs major functions are power supply, multiplexer control, signal measurement, demodulation, filter and control, and waveform generation and synchronization. Several data collection strategies (the way data is gathered through electrodes, number of measurements etc) can 
be used such as linear, diagonal, conducting boundary and adjacent. In the present work, we have used adjacent strategy.

In adjacent strategy, current is injected using a pair of neighboring electrodes and voltage differences are measured using all other pairs of neighboring electrodes. This strategy requires minimal hardware for image reconstruction. Overall schematic on ERT is as shown in Figure 3. 


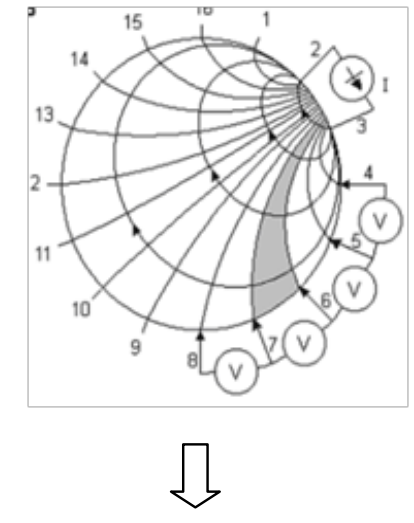

16 Electrodes

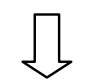

Current is injected using a neighboring pair of electrodes and voltage differences are measured<smiles>C1CCCC1</smiles>

Current is then applied through the next pair of electrodes and the voltage measurements are repeated. The procedure is repeated until all the independent measurements have been made.

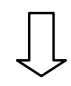

Normal adjacent measurement strategy leads to $\mathrm{n}^{2}$ measurements i.e. 256
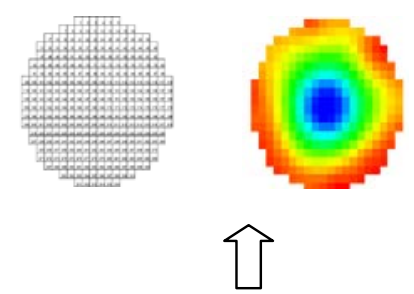

Every c/s view contains 316 pixels to form tomogram<smiles>C1CCC1</smiles>

These measurements /data points used for image reconstruction algorithms to reconstruct c/s distribution of electrical conductivity

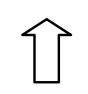

16 Electrodes give 104 independent measurements

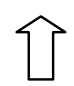

To avoid electrode contact impedance problems, the voltage is not measured at current-injecting electrode and therefore, total number of independent measurements is reduced to $n(n-3) / 2$

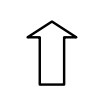

Out of which only 120 measurements are independent i.e. $n(n-1) / 2$

Figure 3: Schematic Representation of ERT (Sardeshpande et al., 2016) 


\section{Methodology}

\section{1 Electrical Resistance Tomography for gas hold up}

Measurements were taken by ERT system for different gas flow rates and impeller speeds. Mean conductivity and mean concentration data was directly exported using ITS Tool suite software in .csv format for gas holdup measurements. The raw pixel conductivity data was used to study the radial profile of the process and flow regime identification.

The variation in conductivity of the dispersed phase was acquired from the ERT data using ITS Tool suite. A concentration value of the dispersed phase is calculated by Tool suite software by Maxwell's Equation:

$\varepsilon_{M}=\frac{2 \sigma_{1}+\sigma_{2}-2 \sigma_{m c}-\sigma_{m c} \sigma_{2} / \sigma_{1}}{\sigma_{m c}-\sigma_{2} / \sigma_{1}+2\left(\sigma_{1}-\sigma_{2}\right)}$

If the second phase is non-conductive material i.e. nitrogen in this case, the above equation reduces to:

$\varepsilon_{M}=\frac{\sigma_{1}-\sigma_{m c}}{\sigma_{1}+0.5 \sigma_{m c}}$

Sample raw data of conductivity (see Figure 4) clearly shows conductivity of continuous phase (i.e. tap water) whereas fluctuations were taken place with respect to time when gas dispersion introduced inside the fluid domain (i.e. at 200l/h). Raw conductivity data reflected clearly the presence of gas by showing reduced conductivity of continuous phase inside the vessel. The conductivity averaged over the cross section at each plane was used to estimate average gas hold-up. The dynamic data was used to identify various flow regimes. ERT experiments were repeated thrice to ensure the reproducibility. 

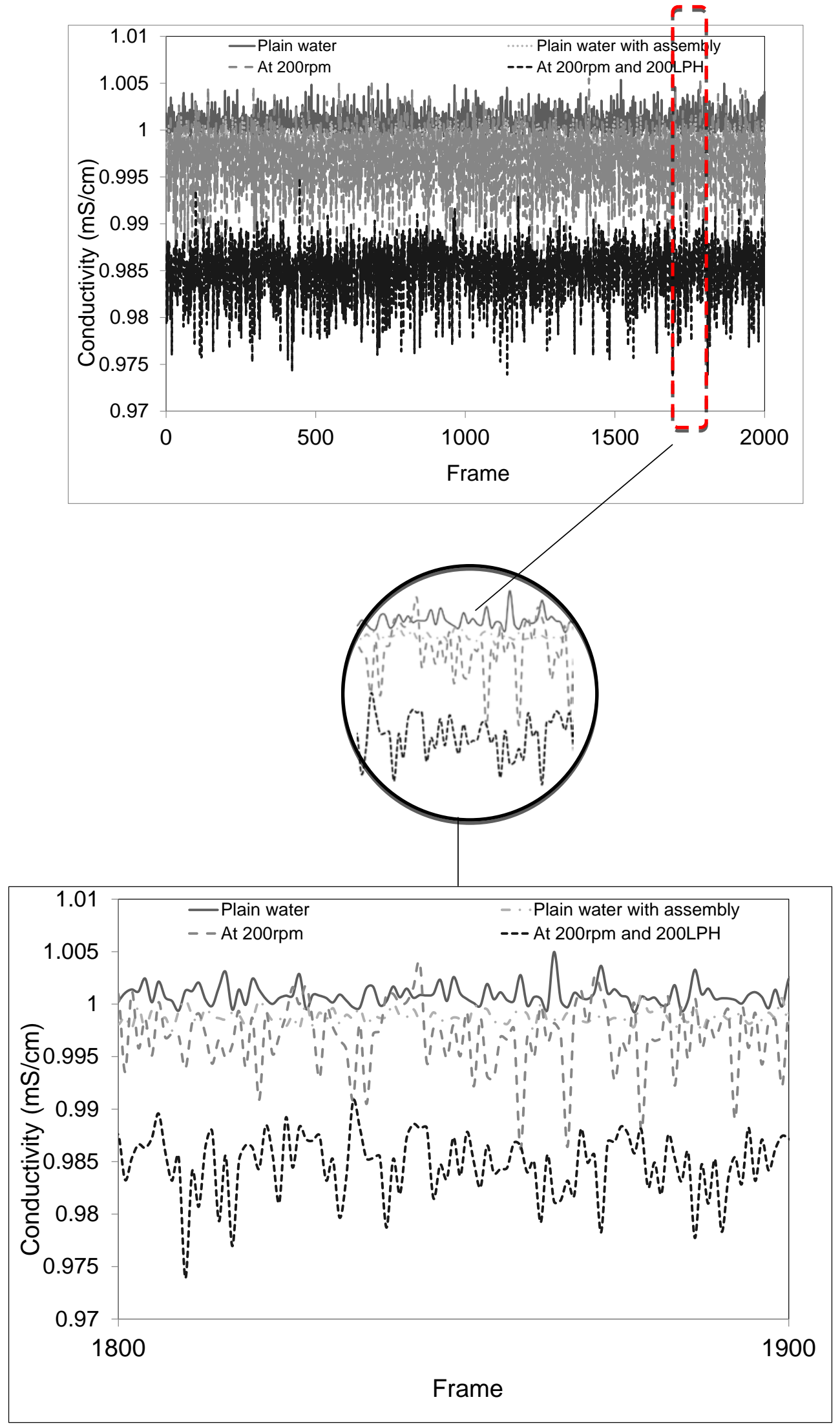

Figure 4: Variation in raw conductivity data 


\subsection{Heterogeneity Index (HIT) Statistic}

During the course of experiments, gas was sparged at a specified flow rate. At different gas flow rates, a heterogeneous mixture was established. The structure of heterogeneous mixture was expressed in terms of the Heterogeneity Index (HIT) Statistic. These values were directly obtained for every frame, using the Tool suite software. For computing HIT, all the pixels were assigned as ranks. In homogenous flow, the bubbles were uniformly distributed throughout the vessel; pixel ranks will also be uniformly distributed. Likewise, in heterogeneous flow where bubbles coalesce and clustering of pixel ranks will be observed. It has been cited in Bennett et al., 1999, as per the following

$$
\begin{aligned}
& H=\left(\frac{6}{55}\right) \sum_{i=1}^{10} \frac{\sum_{j \epsilon A_{i}} r_{j}}{n_{i}}-33 \\
& Z=\frac{H-9}{18^{0.5}}
\end{aligned}
$$

where $r_{j}$ is the rank of pixel $j_{,} K_{i}$ is the $t$ he zone, and $n_{i}$ is the number of pixels in the th zone, $\mathrm{H}$ is the test statistic, $\mathrm{Z}$ is the HIT statistic

It has been observed that bubbles coalesced at or near the impeller, rather than at the periphery near the walls. Thus, each pixel was assigned a rank that decide HIT index

Figure $5 a$ showed mean concentration scattered plot of heterogeneity at 200rpm and 200l/h and $400 \mathrm{l} / \mathrm{h}$. Figure 5a clearly indicated that at low gas flow rate mean concentration of gas was low and it increased with increased gas flow rate. Thus, HIT statistic have shown an increase in the HIT index with increasing flow rate indicating that heterogeneity of the system increased with increasing the flow rate (see Figure 5b). 


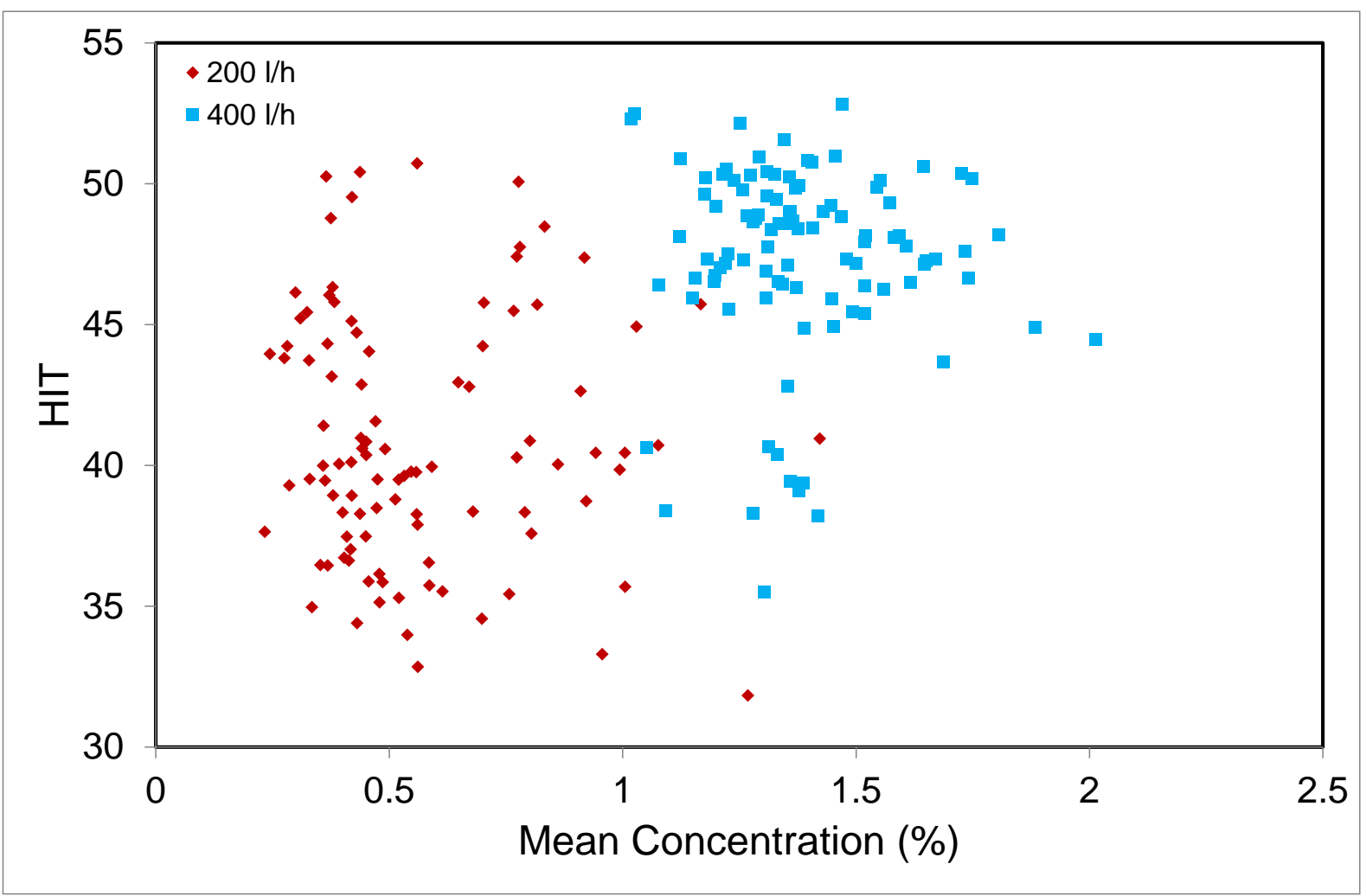

Figure5a: HIT vs Mean concentration scatter plot for 200 rpm impeller speed

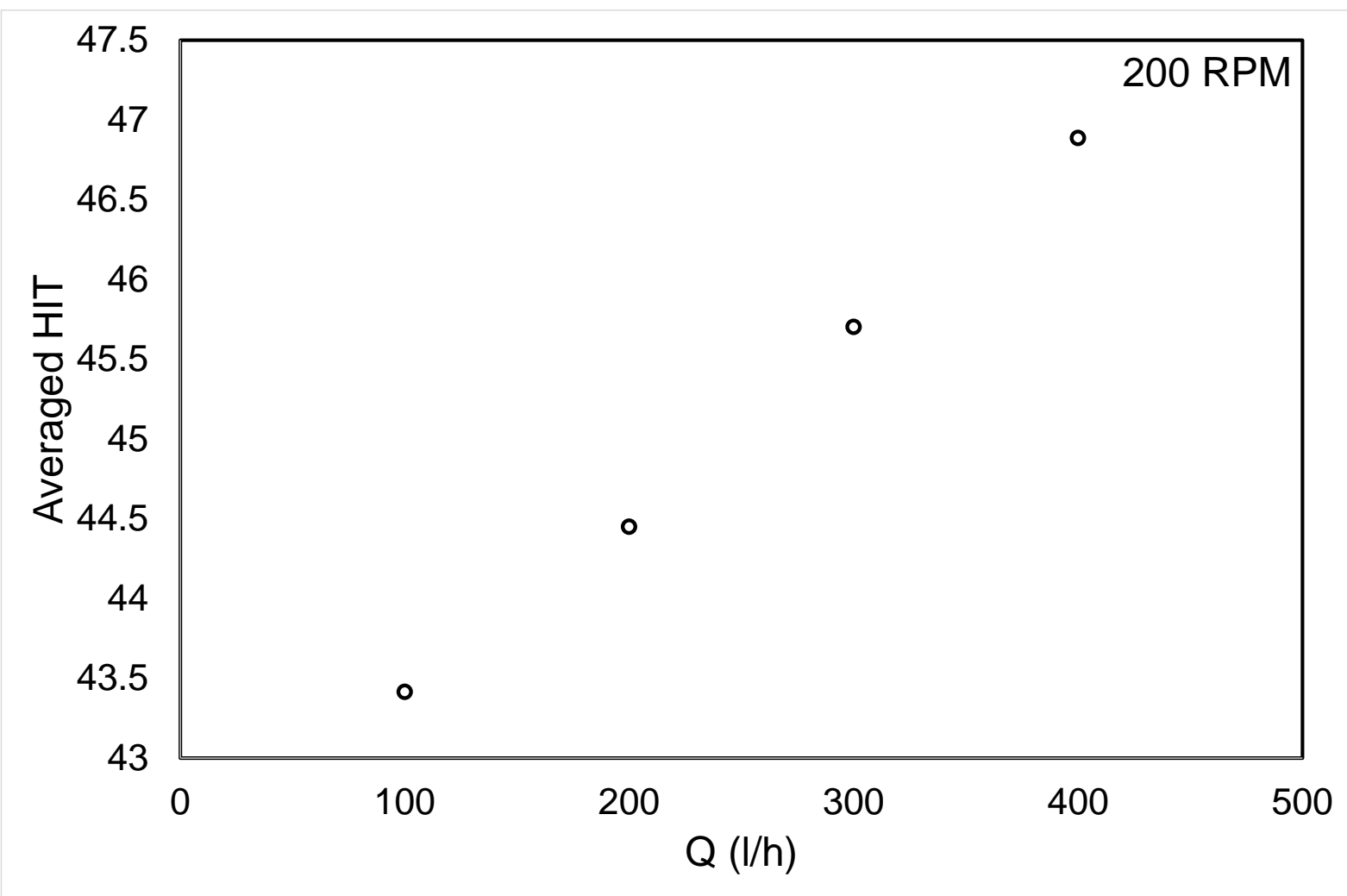

Figure5b: HIT statistic with increasing flow rate

The conductivity and Heterogeneity Index Statistic (HIT) data was directly exported and saved in .csv format. The quantitative conductivity data of each pixel of each tomogram was also used to understand gas distribution inside the vessel. 


\subsection{Visual Measurement Method}

Gas hold up was also measured with conventional technique i.e. flow visualization using the naked eye. The gas was passed through a fixed amount of water, initially at the minimum flow rate. The average height of water was marked on the column using a marker, after which the flow rate was changed. Once the heights for all four flow rates had been marked, the gas valve was momentarily closed and the level of water marked. In this way, the lowest height was the height of the fixed initial volume of water filled in the column, which was denoted as $h_{i}$. This value was subtracted from the height obtained for each flow rate, and the obtained difference was denoted by $\Delta h_{j}$. Since the height of water increased due to the additional volume occupied by gas, the gas hold up was calculated as follows:

$$
\varepsilon_{g=} \frac{\Delta h_{j}}{h_{i}}
$$

where $\mathrm{j}$ takes values from 1 to 5 , representing various flow rates

Reproducibility of results was checked by repeating the experiments thrice.

\section{Results and Discussions}

The results obtained with the ERT, their comparison with visual measurements and previously published results are discussed here.

Tomograms extracted from the real time measurements gave the visual information of the process. The low conductivity regions produced due to gas (non-conductive phase) dispersion (i.e. depicted by blue color) and the high conductivity regions produced due to water (conductive phase) present in the vessel (i.e. majorly visible in light green color). The conductivity of plain tap water was measured using ERT that was well within the range of conductivity reported for plain tap water (see Table 4). 
Table 5: Tap Water Conductivity

\begin{tabular}{|l|l|}
\hline Reference & Tap Water Conductivity (mS/cm) \\
\hline$\underline{\text { http://www.eco-web.com/edi/111219.html }}$ & $0.992-2.492$ \\
\hline$\underline{\text { http://wqaa.gov.in/WriteReadData/UserFiles/Do }}$ & $0.750-2.250$ (Medium Water Class) \\
\hline$\underline{\text { cuments/WaterQualityStandards.pdf }}$ & \\
\hline Present Study (Using ERT) & $\begin{array}{l}0.9989-1 \text { ( } \pm 0.005) \quad \text { (green region in } \\
\text { tomogram) }\end{array}$ \\
\hline
\end{tabular}

\subsection{Effect of gas flow rate}

Experiments were carried out to develop an understanding regarding variation of gas holdup using ERT technique. Tomograms, the reconstructed images from the ERT and surface plots were generated for each flow rate conditions. Tomograms acquired from ERT were compared with photography at different flow rates as shown in Figure 6. The colors represent the conductivity values of pixel, across the entire cross section of the vessel. The boundaries were light green throughout the vessel indicated conductivity of water whereas presence of gas lowers this conductivity inside the vessel at few locations. From the Figure 6, it was clear that as the flow rate increased, gas passes through the water showed its presence with discrete bubbles coalescing into a larger entity. Figure 6 showed increase in the gas flow rate resulted in a gradual increase of low conductivity region across the cross section indicating the presence of the low conductive Nitrogen inside the vessel. Hence, gas flow increased from $100 \mathrm{Iph}(\mathrm{FI}=0.016)$ to 400lph $(F I=0.065)$ the gas holdup values increased at constant impeller speed. 
Stacked images were extracted from ITS tool suite; basically it simplified the visualization of the conductivity distribution for various flow rates. The basic objective for obtaining stacked images was to see dispersion of gas in water within the vessel with greater intricacy. Images i.e. fixed number of 10 consecutive frames could be stacked together to form a spatiotemporal series. Composite images from the same measurement plane (but taken from different frames) can be stacked. These were viewed through a section in the $\mathrm{x}$ and $\mathrm{y}$ plane. In this case the z-axis behaves as a distance axis and the graphic provided a snapshot of what is happening within a vessel at a certain time. Knowledge on the diameter of the vessel and the distance between measurement planes allows interpolation by the insertion of layers between images to give the graphic the right aspect ratio. It was observed in the

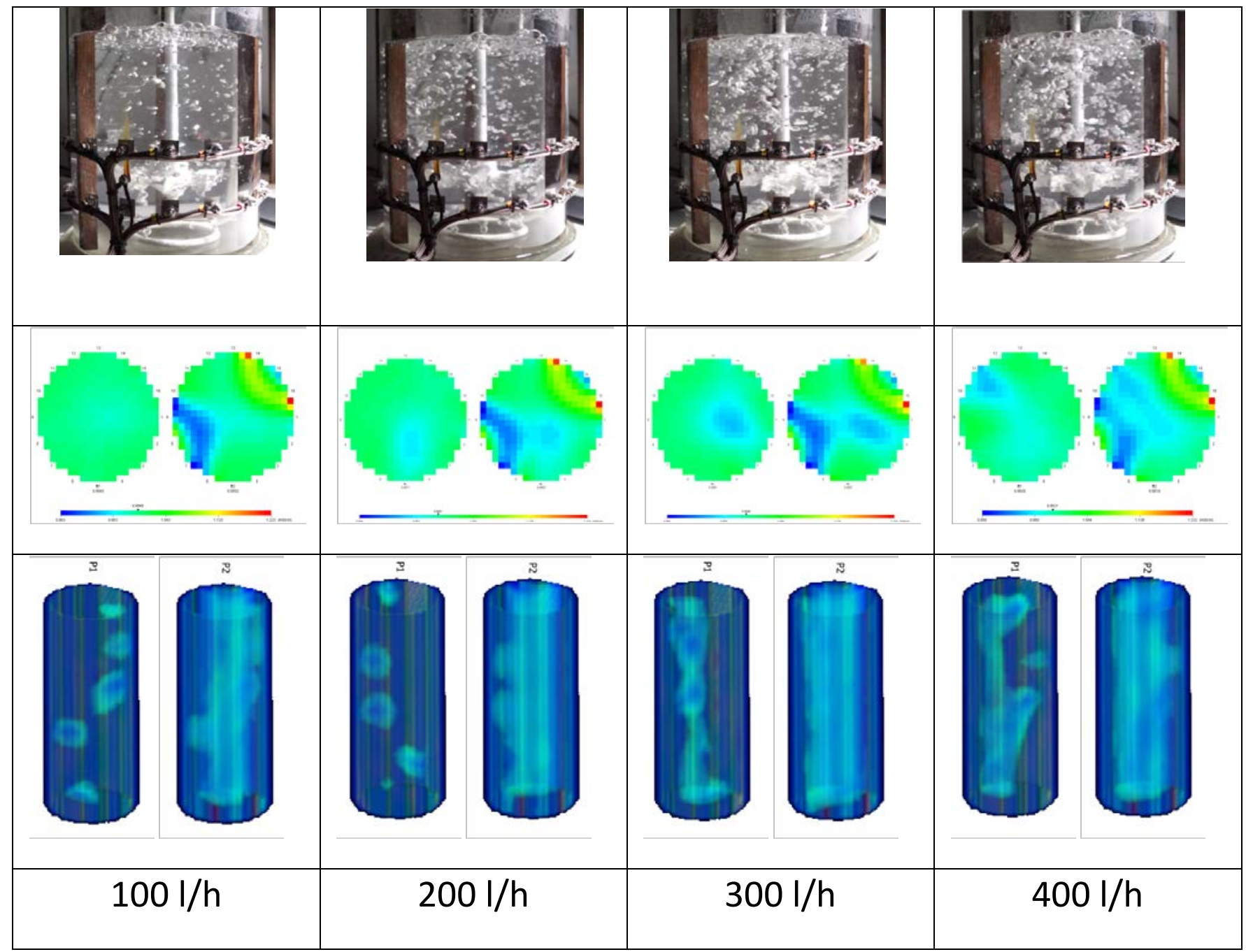

Figure 6: Effect of gas flow rates at 200rpm 
stacked images (Figure 6) that the flow pattern for 100lph $(F I=0.016)$ and 200lph $(\mathrm{Fl}=0.033)$ flow rate was well dispersed and the low conductivity regions in the plane were well dispersed along the vessel axis as well as periphery. Whereas the flow dispersion for $300 \mathrm{Iph}(\mathrm{Fl}=0.049)$ and $400 \mathrm{lph}(\mathrm{Fl}=0.065)$ showed significant low conductivity region near the impeller. The transition clearly showed the shift of flow pattern from dispersed phase to a flooding/ loading regime.

Surface plots were plotted for both the planes such as Figure 7a and $7 \mathrm{~b}$ respectively. These were the quantitative representation of the gas holdup across the cross-section of the vessel at any particular time. The surface plot generated for a single frame with the conductivity data using Matlab code for different operating conditions. Firstly, the gas hold-up data for 316 pixels across the cross section of the vessel that was then plotted on a $x-y$ plane of $20 x$ 20 matrix and the $z$ axis being the gas holdup values of each pixel. A significant disturbance and a peak of rising gas holdup value near the impeller were visible. As predicted, this clearly showed the transition of flow from flooding/ loading to completely dispersed condition of the impeller. Estimated gas hold up using ERT data plotted with respect to superficial gas velocity is as shown in Figure 8. 
$100 \mathrm{l} / \mathrm{h}$

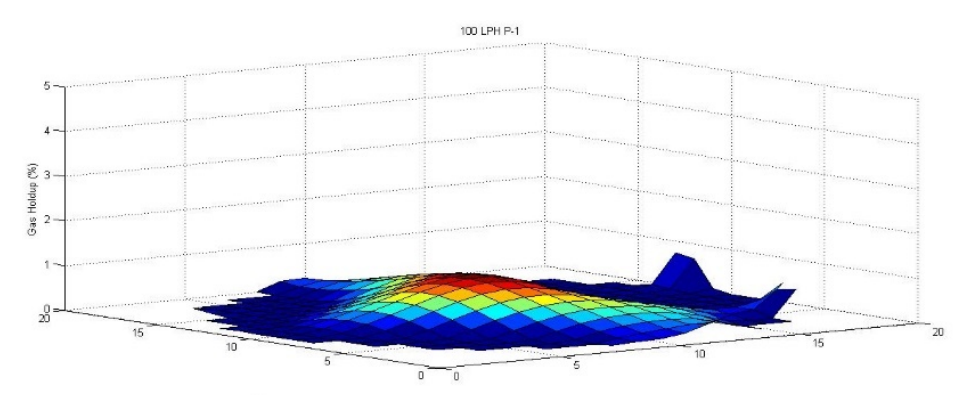

$300 \mathrm{l} / \mathrm{h}$

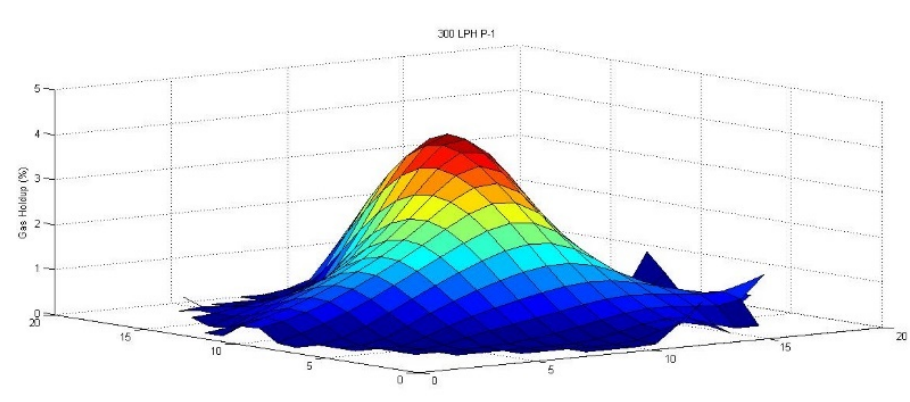

$200 \mathrm{l} / \mathrm{h}$

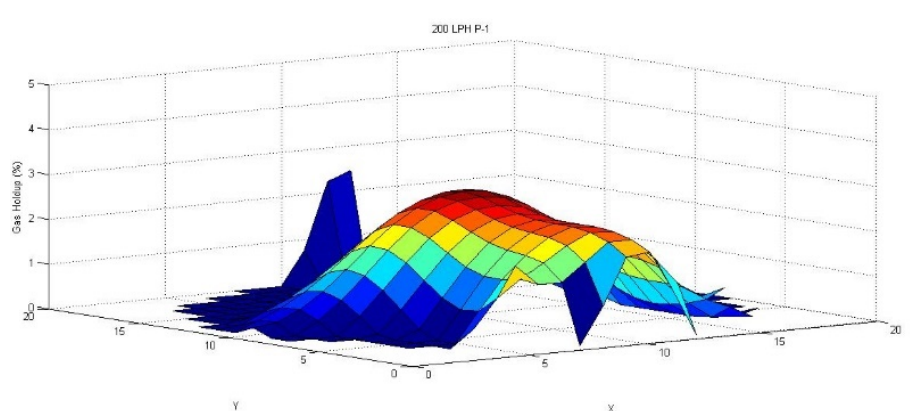

$400 \mathrm{l} / \mathrm{h}$

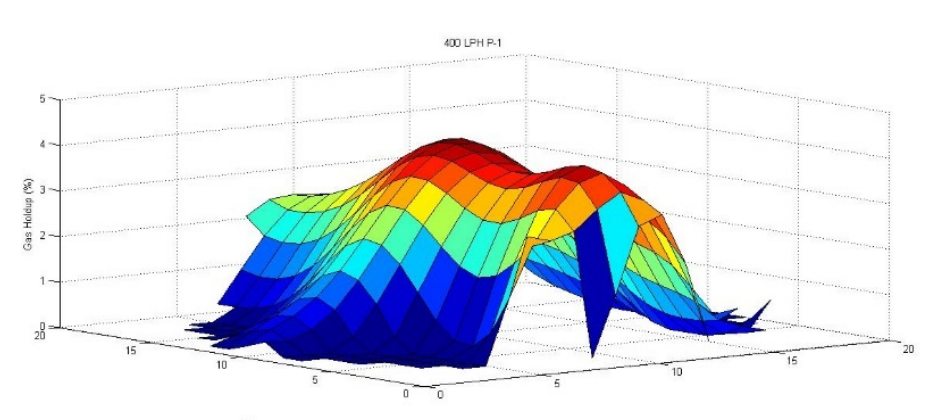

Figure 7a: Gas holdup profiles by MATLAB for 200rpm impeller speed - Plane-1 
$100 \mathrm{l} / \mathrm{h}$

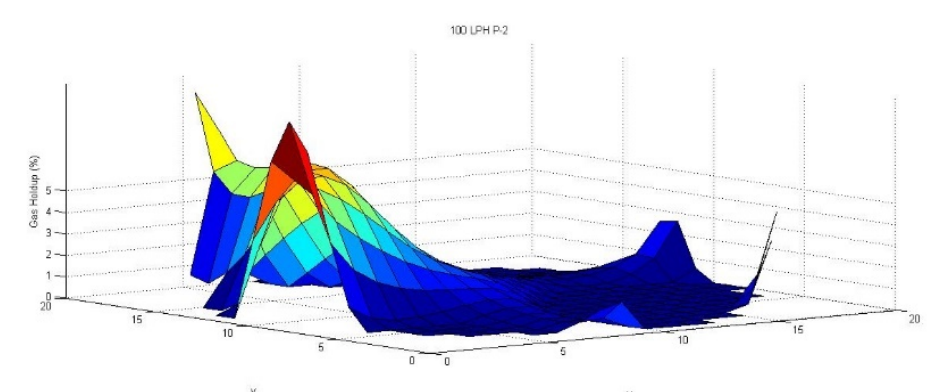

$300 \mathrm{l} / \mathrm{h}$

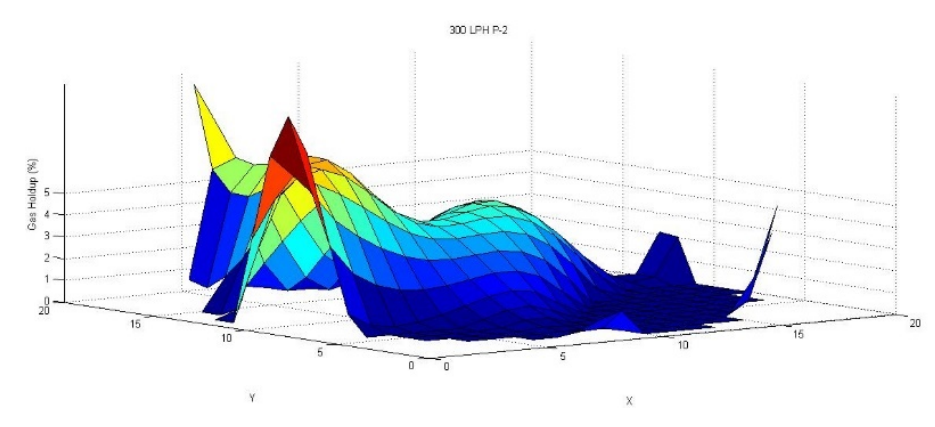

$200 \mathrm{l} / \mathrm{h}$

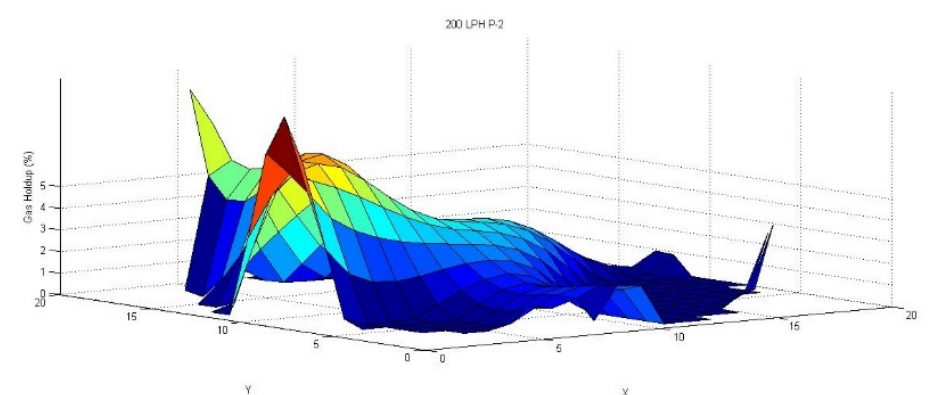

$400 \mathrm{l} / \mathrm{h}$

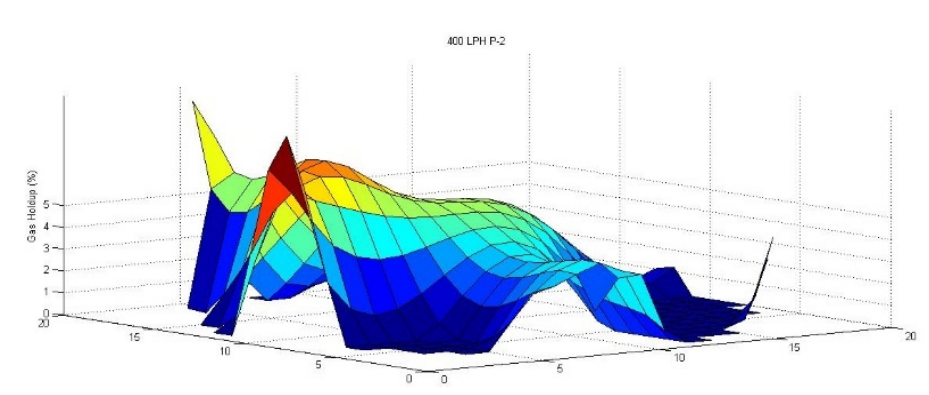

Figure 7b: Gas holdup profiles by MATLAB for 200rpm impeller speed - Plane-2 


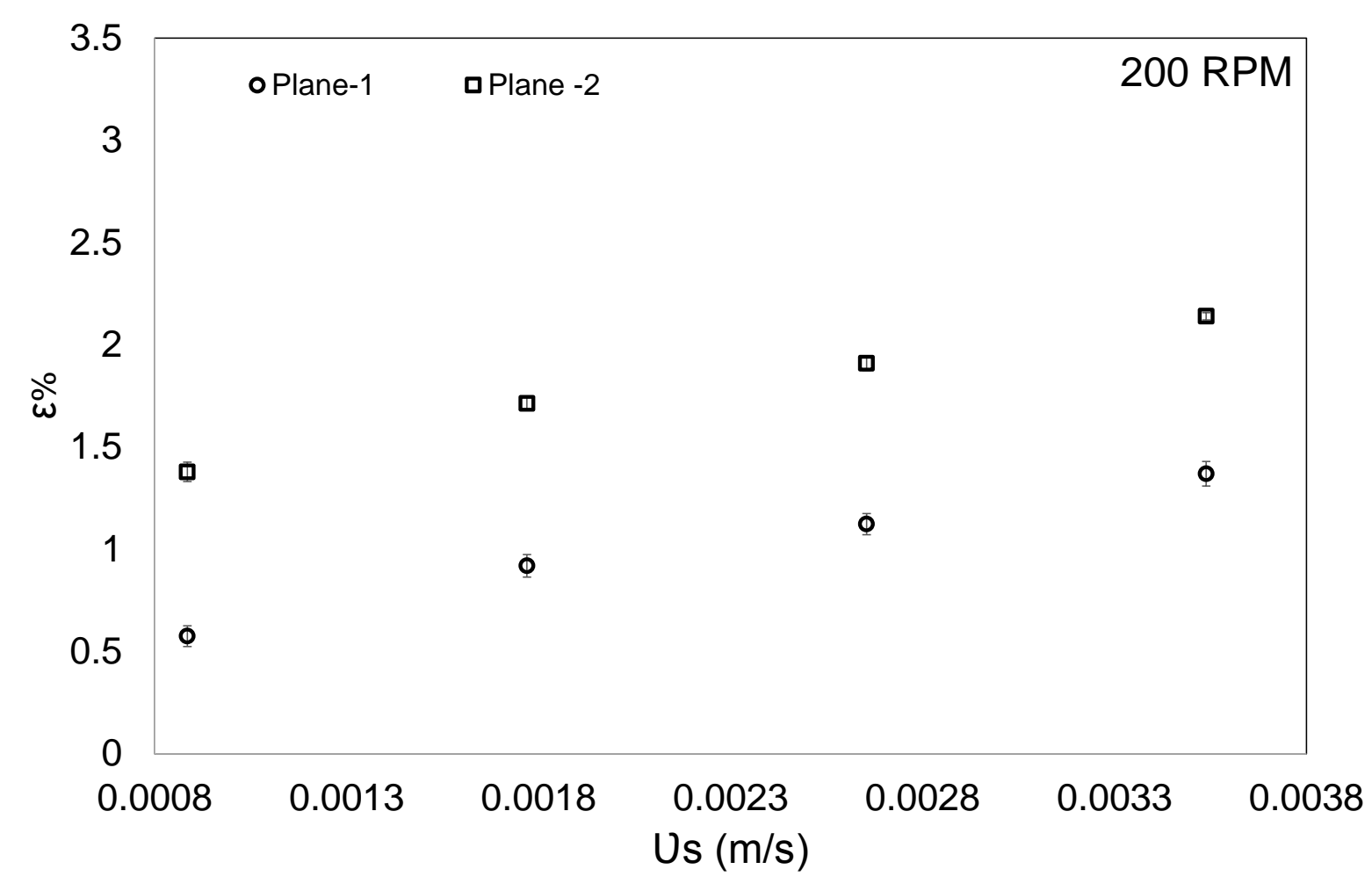

Figure 8: Effect of superficial velocity on gas holdup 


\subsection{Effect of I mpeller Speed}

Figure 9 showed the extracted tomograms from the ERT Technique. As it observed that in Plane- 1 there is a gradual increase in the low conductivity region from $100 \mathrm{rpm}(\mathrm{Fr}=0.0082)$ to $400 \mathrm{rpm}(\mathrm{Fr}=0.1306)$ indicating the presence of gas across the cross section of the vessel. Further it observed that at $100 \mathrm{rpm}(\mathrm{Fr}=0.0082)$ and $200 \mathrm{rpm}(\mathrm{Fr}=0.0327)$, the plane -1 has not registered much of low conductivity regions and it has been mainly concentrated in the center of the tomogram suggesting the presence of less amount of gas which was mostly confined at the center of the vessel. Hence, it can be inferred that the flow pattern is in flooding/ loading regime that can be validated from the photography and the flow regime map (Figure 2). Further, in the tomograms for higher impeller speeds i.e. 300rpm ( $\mathrm{Fr}=0.0735)$ and $400 \mathrm{rpm}(\mathrm{Fr}=0.1306)$, a dense and dispersed low conductivity region in both Plane-1 and Plane- 2 was observed. This clearly shows the presence of gas both above and below the impeller suggesting a transition of the flow pattern to limited recirculation and complete dispersion. Figure 10 showed the surface plots where the peaking gas holdup near the impeller in comparison to the periphery indicating the presence of gas flow mostly near the impeller suggesting the flooding/loading of the impeller. The dispersion can also be seen in the surface plots for $300 \mathrm{rpm}(\mathrm{Fr}=0.0735)$ and $400 \mathrm{rpm}(\mathrm{Fr}=0.1306)$ that showed well dispersed gas holdups across the cross section of the vessel confirming the inferences drawn.

It was observed that gas holdup was not monotonically increased with increased impeller speed whereas both the planes showed a rise-dip-and-rise pattern (See Figure 11). This rise-dip-rise flow pattern observed because the ERT plane-1 i.e. positioned below the impeller (facing both upward and downward) could detect few bubbles until the operating conditions nearly reached the fully re-circulated regime; and at the plane-2 i.e. above 
impeller discharge plane detected more gas hold up but still showed rise-dip-rise flow pattern. This was consistent and showed the location sensitivity of the ERT planes.

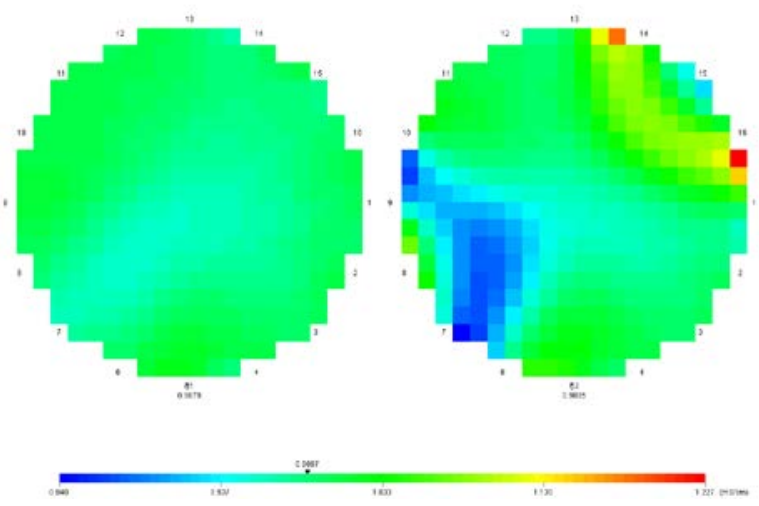

$100 \mathrm{rpm}$

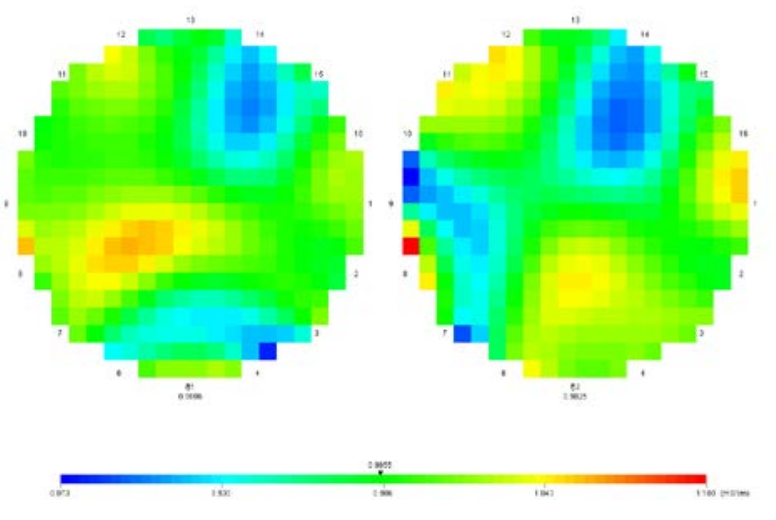

$200 \mathrm{rpm}$

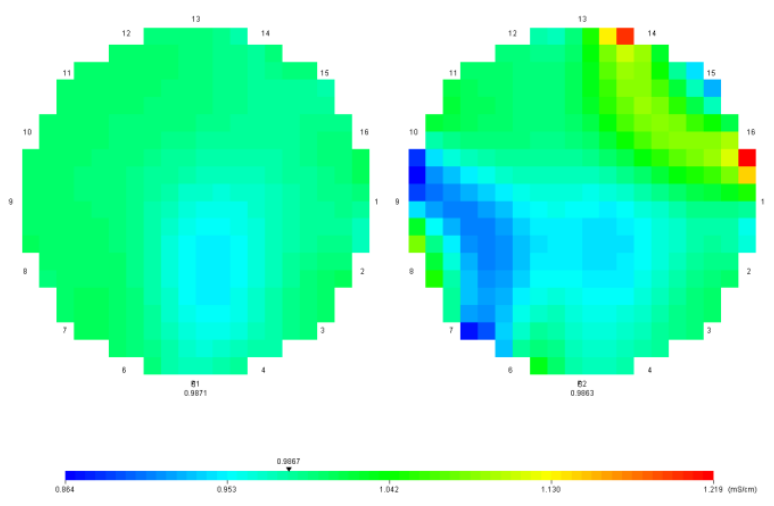

$300 \mathrm{rpm}$

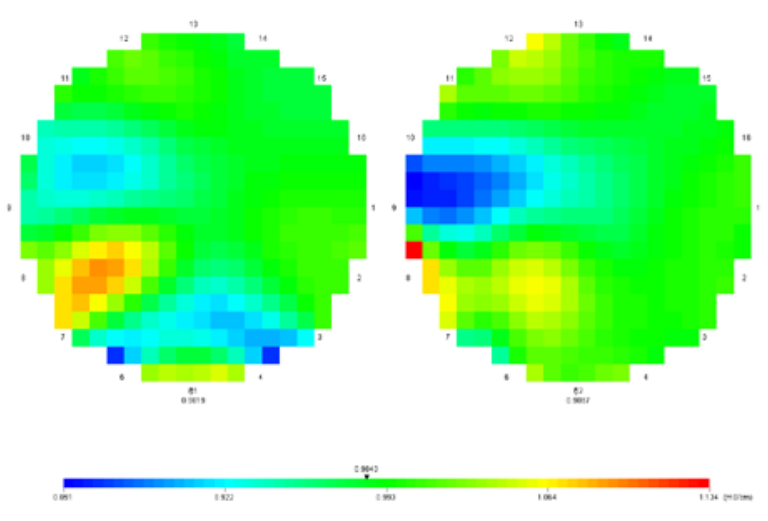

$400 \mathrm{rpm}$

Figure 9: Tomograms showing liquid-gas distribution for $300 \mathrm{l} / \mathrm{h}$ gas flow rate 
100 rpm

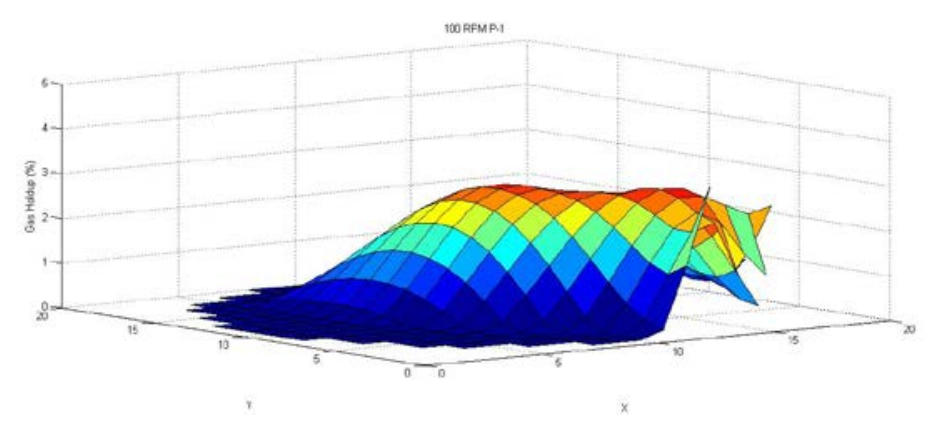

200 rpm

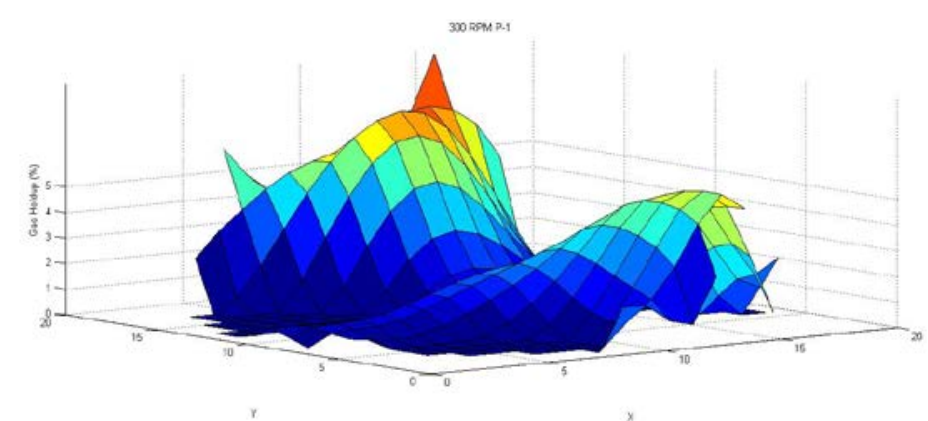

300 rpm

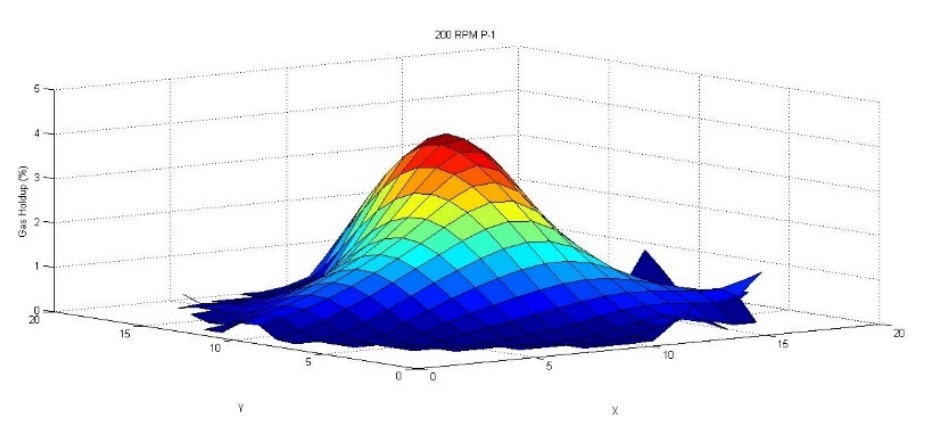

$400 \mathrm{rpm}$

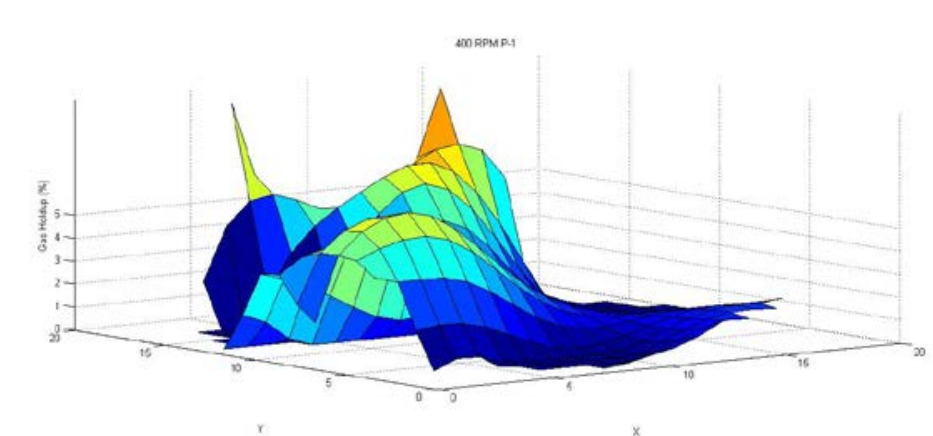

Figure 10a: Gas holdup profiles by MATLAB for $300 \mathrm{l} / \mathrm{h}$ gas flow rate - Plane-1 
$100 \mathrm{rpm}$

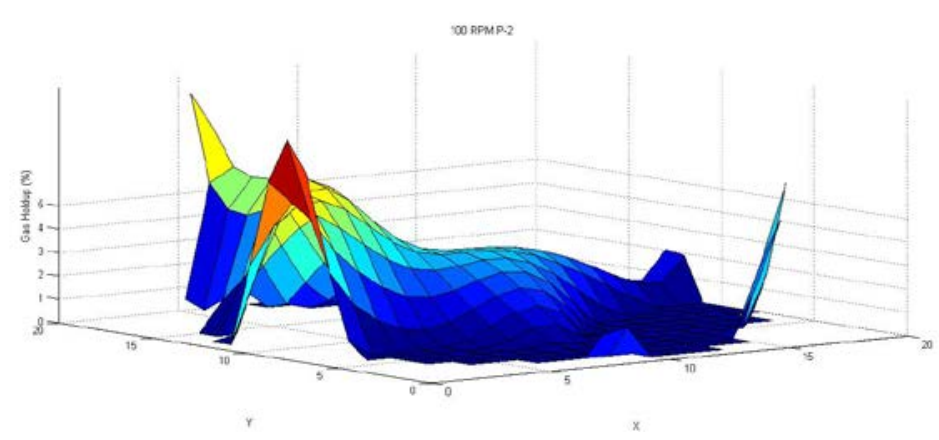

$300 \mathrm{rpm}$

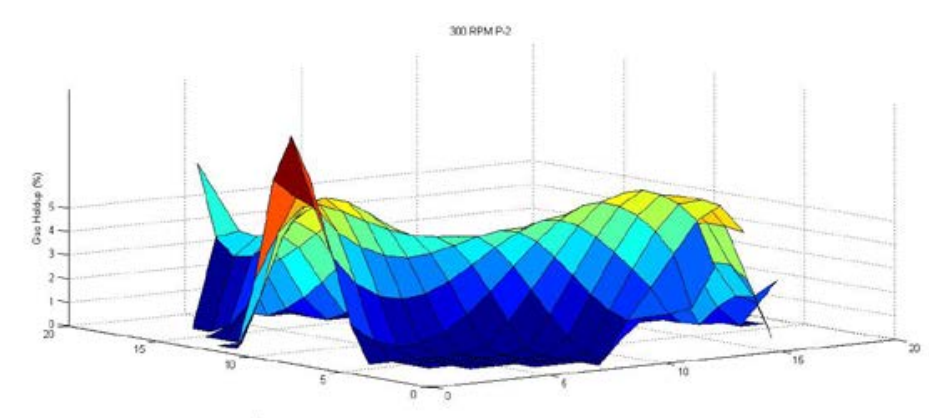

$200 \mathrm{rpm}$

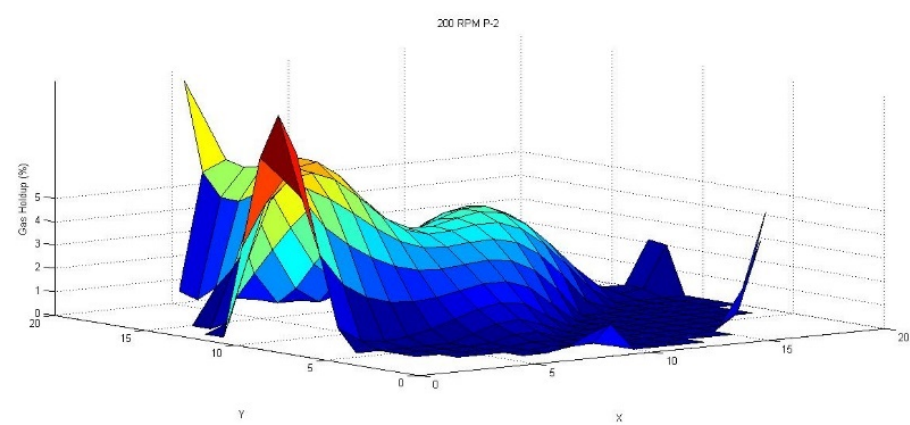

$400 \mathrm{rpm}$

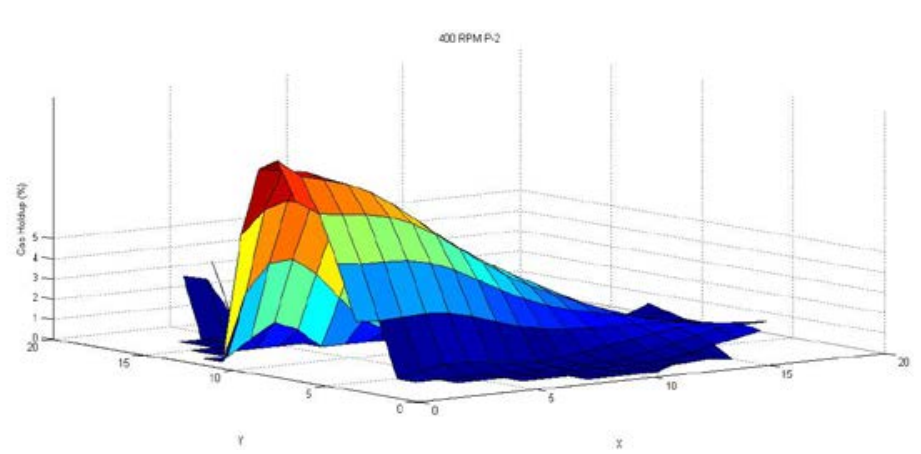

Figure 10b: Gas holdup profiles by MATLAB for 300 I/h gas flow rate - Plane-2 


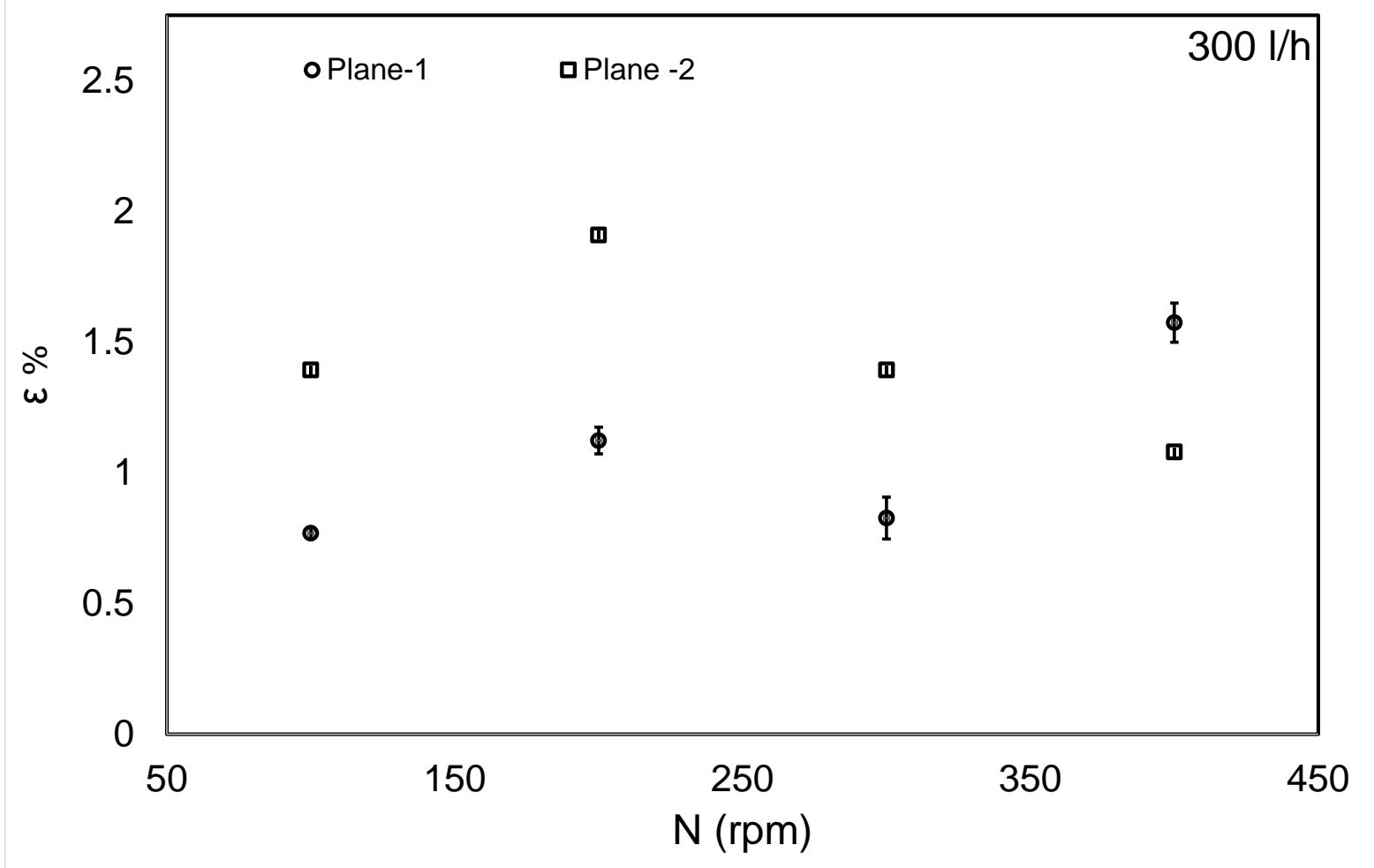

Figure 11: Effect of impeller speed on gas holdup 
5.3 Comparative study of ERT, Visual Measurement and Correlations

ERT measurements were compared with the visual observations and reported correlations as shown in Figure 12a and 12b. Gas holdup was averaged across circumferential plane and compared with visual measurements. It was observed that ERT Plane-1 data over predicted compared to the correlation of Yawalkar et al., (2002) and Greaves and Barigou (1990), under predicted compared to the correlation of Rewatkar (1993) and agrees well with that of Smith (1991). Plane-2 data under predicted Rewatkar (1993) and over predicted in comparison with Yawalkar et al., (2002) and Greaves and Barigou (1990). It observed that gas hold up measured at Plane-1 was under predicted whereas the Plane-2 over predicted because it indicated higher gas distribution as of circulation pattern of RT. 


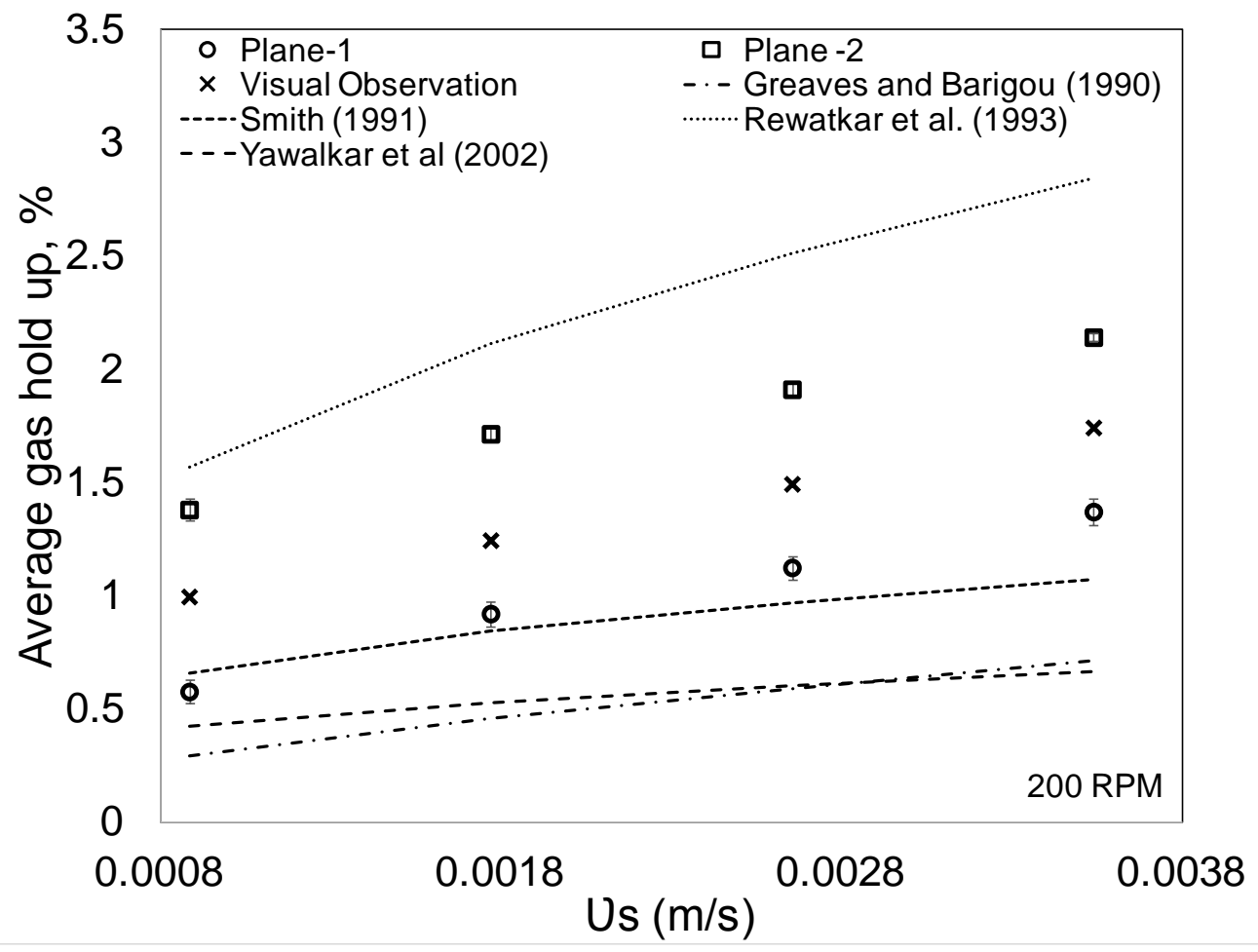

Figure 12a: Comparison of gas holdup with visual measurement and reported correlations with respect to superficial gas velocity

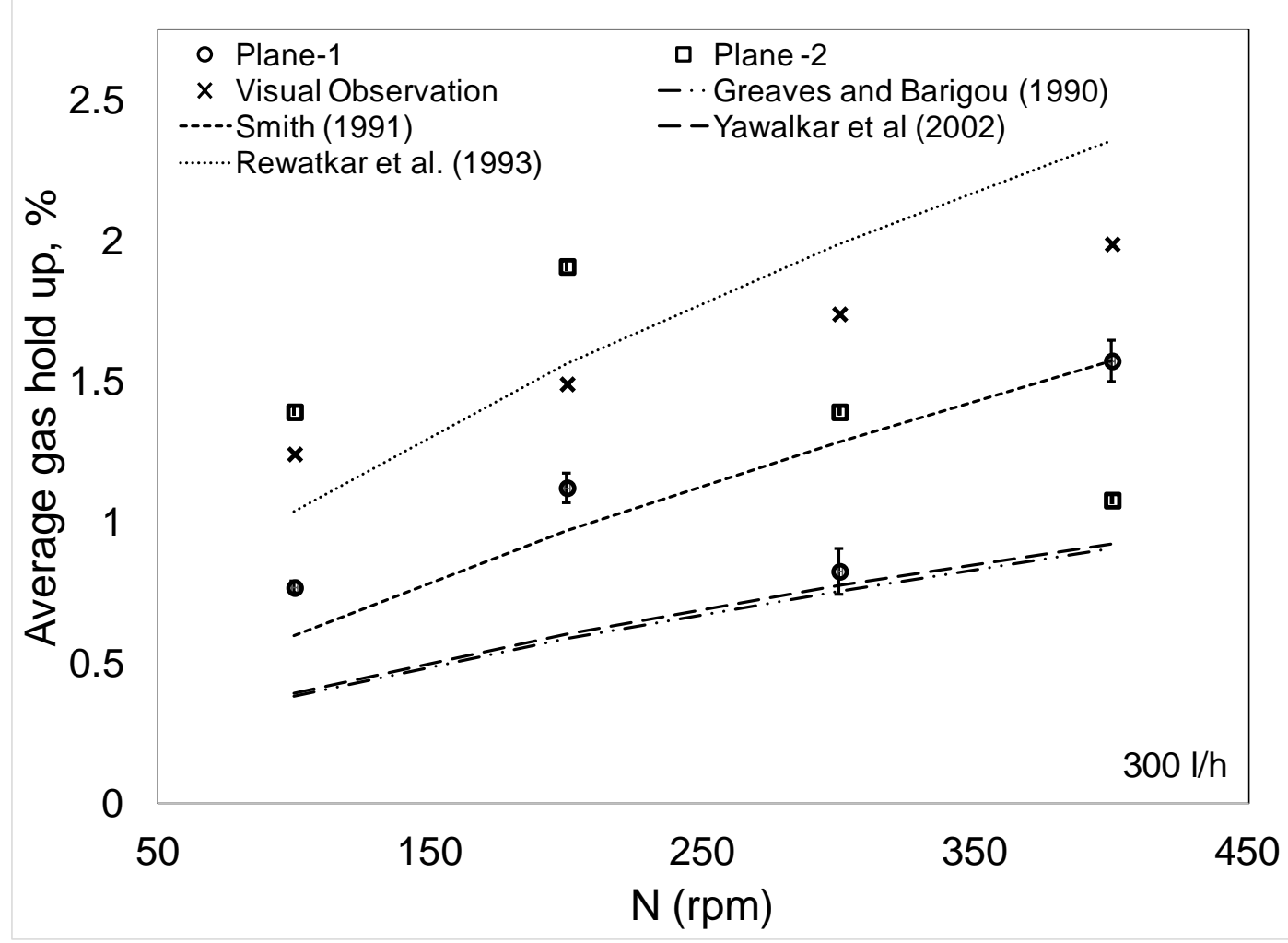

Figure12b: Comparison of gas holdup with visual measurement and reported correlations with respect to impeller speed 


\section{Conclusions}

The variation of gas holdup with respect to gas flow rate and impeller speed was studied in a gas-liquid STR using ERT technique. Identification of flow regimes was done using ERT raw data and was verified with visual analysis. The key conclusions of this study are:

(i) ERT technique provides useful data on gas hold-up distribution within the vessel and captures influence of impeller speed and gas velocity on gas distribution correctly.

(ii) ERT data processed for plane-1 and plane-2 and averaged gas hold up used to identify change in flow regime from circulation to flooding.

(iii) Gas holdup monotonically increased for the two planes that were positioned below and above the impeller discharge plane as the Fl number increased. This matches well with visual observation, as the reactor transitioned to a more dispersed regime as the FI number increased.

(iv) With increasing impeller speed; gas-hold up showed a rise-dip-and-rise pattern because of transition of regime (2-D plots such as tomograms when the $\mathrm{FI}$ constant and the 3-D plots such as surface plots).

(v) Comparison of average of two planes and visual measurement shows well in agreement in Figure $12 \mathrm{a}$ and at least first two points of Figure $12 \mathrm{~b}$. Whereas comparison for the most of the results are better than $\pm 30 \%$.

(vi) Heterogeneity index is a good measure of mean concentration of gas distribution at each plane that provides uniformly distributed pixel ranks (i. e. for uniformly distributed bubbles) whereas clustering of pixel ranks observed for heterogeneous flow. 
(vii) Gas Holdup obtained from ERT at Plane - 1 and Plane - 2 under predicted 10 to $30 \%$ as compared to Rewatkar et al ${ }^{35}$ whereas with visual observation $\pm 30 \%$ for Plane - 1 and Plane - 2 respectively.

(viii) In present attempt of ERT experimentation; it was observed that each plane showed its own sensing range of gas distribution and spatial visualisation inside the tank. Whereas more number of planes could prove giving more accurate data and pronounced information about the gas behaviour inside the vessel.

Thus, the electrical resistance tomography (ERT) was successfully used to measure gas distribution in a gas-liquid stirred reactor in response to design and operating conditions. ERT technique provides the required information to experimentalist to evaluate this technology at higher gas loading and an opaque system. The methodology and results presented in this work will be useful to effectively apply ERT for characterizing gas-liquid flows in stirred tanks.

\section{Acknowledgement}

Authors are grateful to financial support for this work by CSIR through Mastflo project [OLP3026]. One of the authors [MVS] is also grateful to DST women scientist scheme [GAP297326], INDI A for sponsoring the research and providing test facilities. 


\section{Nomenclature}

A: Cross Sectional Area of the Tank $\left(\mathrm{m}^{2}\right)$

D: Impeller Diameter

Dp: 6-Pitched Blade Turbine Diameter (cm)

$D_{R}$ : Rushton Turbine Diameter (cm)

Fl: Flow Number

Fr: Froude Number

g: gravity of earth $\left(9.8 \mathrm{~m}^{2} / \mathrm{s}\right)$

$\mathrm{H}$ : Height of the Liquid $(\mathrm{cm})$

$\mathrm{H}_{\mathrm{o}}$ : Height of liquid when ungassed $(\mathrm{cm})$

$\mathrm{H}_{\mathrm{g}}$ : Height of liquid when gassed $(\mathrm{cm})$

$\mathrm{N}$ : Impeller Speed (rpm)

P: Power (W)

Q: Gas Flowrate (LPH)

Re: Reynolds Number

T: Tank Diameter (cm)

V: Volume of the tank $\left(\mathrm{m}^{3}\right)$

$\varepsilon_{\mathrm{M}}$ : Maxwell's Equation for Gas holdup

$\varepsilon_{v}:$ Gas Holdup Value through Volume Expansion Method

$U_{s}:$ Superficial Velocity $(\mathrm{m} / \mathrm{s})$

$\mu$ : Viscosity of fluid (Pa.s)

$\rho:$ Density of the fluid $\left(\mathrm{kg} / \mathrm{m}^{3}\right)$

$\sigma_{\mathrm{mc}}$ : reconstructed measured conductivity from ERT $(\mathrm{mS} / \mathrm{cm})$

$\sigma_{1}$ : conductivity of the continuous phase $(\mathrm{mS} / \mathrm{cm})$

$\sigma_{2}:$ conductivity of the dispersed phase $(\mathrm{mS} / \mathrm{cm})$

$\mathrm{N}_{\mathrm{p}}$ : Power Number 


\section{References}

1. Abdullah B., Dave C., Nguyen T. H., Cooper C., Adesina A. A., 2009. Hydrodynamics Characterisation of Multiphase Stirred Tank Reactor Using Electrical Resistance Tomography. Challenges for a Changing World, WCCE8, Canada, presented at 8th World Congress of Chemical Engineering, Montreal Canada, 23 - 27 August 2009

2. Abdullah, B., Dave, C., Nguyen, T.-H., Cooper C. G., Adesina A. A., 2011. Electrical resistance tomography assisted analysis of dispersed phase hold-up in a gas-inducing mechanically stirred vessel. Chemical Engineering Science 66(22), 5648-5662.

3. Aw, S. R., Rahim R. A., Rahiman, M. H. F., Yunus F. R. M., Goh C. L., 2014. Electrical resistance tomography: A review of the application of conducting vessel walls. Powder Technology 254(0), 256-264.

4. Bennett, M.A., West, R.M., Luke, S.P., Jia, X., Williams, R.A., 1999. Measurement and analysis of flows in a gas-liquid column reactor. Chemical Engineering Science $54,5003-5012$.

5. Cents, A.H.G., Brilman, D.W.F., Versteeg, G.F., 2005. Ultrasonic investigation of hydrodynamics and mass transfer in a gas-liquid (-liquid) stirred vessel. International J ournal of Chemical Reaction Engineering 3, 32.

6. Dave, C. B., Abdullah, B., Vo, D., Nguyen, T. H., Cooper, C. G., Adesina A. A., 2009. ERT measurement of gas hold-up distribution in bubble column with coalescence inhibiting solutions. Proceeding of the 8th World Congress of Chemical Engineering (WCCE8), 23rd-27th August.

7. Dickin, F., Wang, M., 1996. Electrical resistance tomography for process applications. Measurement ScienceTechnology 7(3), 247-260.

8. Dong, F., Xu C., Zhang Z., Ren S., 2012. Design of Parallel Electrical Resistance Tomography System for Measuring Multiphase Flow. Chinese Journal of Chemical Engineering 20(2), 368-379. 
9. Dong, F., J iang, Z. X., Qiao X. T., Xu, L. A., 2003. Application of electrical resistance tomography to two-phase pipe flow parameters measurement. Flow Measurement and Instrumentation 14(4-5), 183-192.

10. Fransolet, E., Crine, M., Marchot P., Toye D., 2005. Analysis of gas holdup in bubble columns with non-Newtonian fluid using electrical resistance tomography and dynamic gas disengagement technique. Chemical Engineering Science 60(22), 61186123.

11. Fordham, E.J., Holmes, A., Ramos, R.T., Simonian, S., Huang, S.M., Lenn, C.P., 1999a. Multi-phase-fluid discrimination with local fibre-optical probes: I. Liquid/liquid flows. Measurement Science Technology 10, 1329.

12. Fordham, E.J., Ramos, R.T., Holmes, A., Simonian, S., Huang, S.M., Lenn, C.P., 1999b. Multi-phase-fluid discrimination with local fibre-optical probes: III. Threephase flows. Measurement Science Technology 10, 1347.

13. Fordham, E.J., Simonian, S., Ramos, R.T., Holmes, A., Huang, S.M., Lenn, C.P., 1999c. Multi-phase-fluid discrimination with local fibre-optical probes: II. Gas/liquid flows. Measurement Science Technology 10, 1338.

14. Ford, J.J ., Heindel, T.J ., J ensen, T.C., Drake, J.B., 2008. X-ray computed tomography of a gas-sparged stirred-tank reactor. Chemical Engineering Science 63, 2075-2085.

15. Guet, S., Fortunati, R.V., Mudde, R.F., Ooms, G., 2003. Bubble velocity and size measurement with a four-point optical fiber probe. Particle \& Particle System Characterization 20, 219-230.

16. Greaves, M., Barigou, M., 1990. Estimation of gas hold-up and impeller power in a stirred vessel reactor. "Fluid Mixing III", International Chemical Engineering Symposium Series No.108, 235 - 255. 
17. Hampel, U., Hristov, H. V., Bieberle A., Zppe C., 2007. Application of high-resolution gamma ray tomography to the measurement of gas hold-up distributions in a stirred chemical reactor. Flow Measurement and Instrumentation 18(5-6), 184-190.

18. Hassan, I. T. M., Robinson, C. W., 1977. Al ChE J., 23, 48.

19. HUANG Z., HU Y.C., WANG J., YANG Y., 2012. Measurement of critical dispersion speed in stirred tank based on Hilbert-Huang transform JOURNAL OF ZHEJIANG UNI VERSITY (ENGINEERI NG SCIENCE) 46 (9), 1685-1691.

20. J ade, A.M., Jayaraman, V.K., Kulkarni, B.D., Khopkar, A.R., Ranade, V.V., Ashutosh, S., 2006. A novel local singularity distribution based method for flow regime identification: gas-liquid stirred vessel with Rushton turbine. Chemical Engineering Science 61, 688-697.

21. Jin, H., Lian, Y., Qin, Y., Yang S., He, G., 2013. Distribution characteristics of holdups in a multi-stage bubble column using electrical resistance tomography. Particuology $11(2), 225-231$.

22. Jin, H., Yang, S., Wang M., Williams R. A., 2007. Measurement of gas holdup profiles in a gas liquid co-current bubble column using electrical resistance tomography. Flow Measurement and Instrumentation 18(5-6), 191-196.

23. Julia, J.E., Harteveld, W.K., Mudde, R.F., Van den Akker, H.E.A., 2005. On the accuracy of the void fraction measurements using optical probes in bubbly flows. Review of Scientific Instruments76, 035-103.

24. Karimi, A., Golbabaei, F., Mehrnia, M., Neghab, M., Mohammad, K., Nikpey A., Pourmand M. 2013. Oxygen mass transfer in a stirred tank bioreactor using different impeller configurations for environmental purposes. Iranian J ournal of Environmental Health Science \& Engineering 10(1), 1-9.

25. Karimi, A., Golbabaei, F., Mehrnia, M. R., Mohammad, K., Neghab, M., Nikpey A., Pourmand M. R., 2013. Investigation of Gas Hold up and Power Consumption in a 
Stirred Tank Bioreactor Using Single and Dual Impeller Configurations. 5(3), 109116.

26. Khopkar, A.R., Rammohan, A.R., Ranade, V.V., Dudukovic, M.P., 2005. Gas-liquid flow generated by a Rushton turbine in stirred vessel: CARPT/CT measurements and CFD simulations. Chemical Engineering Science 60, 2215-2229.

27. Khopkar, A.R., Ranade, V.V., 2006. CFD simulation of gas-liquid stirred vessel: VC, S33, and L33 flow regimes. Al ChE J. 52, 1654-1672.

28. Kulkarni, A. A., Jha, N., Singh, A., Bhatnagar S., Kulkarni B. D., 2011. Fractal Impeller for Stirred Tank Reactors. Industrial \& Engineering Chemistry Research 50(12), 7667-7676.

29. Lee, B. W., Dudukovic M. P., 2014. Time-series analysis of optical probe measurements in gas-liquid stirred tanks. Chemical Engineering Science 116(0), 623634.

30. Lee, B. W., Dudukovic M. P., 2014. Determination of flow regime and gas holdup in gas-liquid stirred tanks. Chemical Engineering Science 109(0), 264-275.

31. Lee, J. H., Foster, N. R., 1990. Mass Transfer and Solubility of $\mathrm{O}_{2}$ and $\mathrm{CH}_{4}$ in Silicone Fluids. Industrial \& Engineering Chemistry Research, 29, 691.

32. Mueller, S. G., Dudukovic M. P., 2010. Gas Holdup in Gas-Liquid Stirred Tanks. Industrial \& Engineering Chemistry Research 49(21), 10744-10750.

33. Nienow, A.W., Warmoeskerken, M.M.C.G., Smith, J.M., Konno, M., 1985, On the flooding/loading transition and the complete dispersal condition in aerated vessels agitated by a Rushton-turbine, Proc 5th European Conference on Mixing, Wurtsburg, West Germany, 143-154.

34. Paglianti, A., Pintus, S., Giona, M., 2000 Time-series analysis approach for the identification of flooding/loading transition in gas-liquid stirred tank reactors. Chemical Engineering Science 55(23), 5793-5802. 
35. Pinheiro, P. A. T., Loh W. W., Dickin F. J., 1998. Three-dimensional reconstruction algorithm for electrical resistance tomography. Science, Measurement and Technology, IEE Proceedings - 145(3), 85-93.

36. Rewatkar V.B., Joshi, J.B., 1993. Effect of sparger design on gas dispersion in mechanically agitated gas/liquid reactors, Canadian Journal Chemical Engineering, $71,278-291$.

37. Rodgers, T. L. and Kowalski A. 2010. An electrical resistance tomography method for determining mixing in batch addition with a level change. Chemical Engineering Research and Design 88(2), 204-212.

38. Sardeshpande M. V., Kumar G., Aditya T., Ranade V. V., 2016. Mixing studies in unbaffled stirred tank reactor using electrical resistance tomography. Flow Measurement and Instrumentation 47, 110-121.

39. Sarvanan K., Ramamurthy V., Chandramohan K., 2009, Gas hold up in multiple impeller agitated vessels, Modern Applied Science 3(2), 49 - 59.

40. Smith, J. M., 1991. Simple Performance Correlations for Agitated Vessels. "Proc. $7^{\text {th }}$ Euro. Congress on Mixing Brugge , 233-241

41. Takriff, M. S., Ahmad, A., Rosli M. I., Jantan S., 2013. ERT Visualization of Gas Dispersion Performance of Aerofoil and Radial Impellers in an Agitated Vessel. J urnal Teknologi 64(5).

42. Takriff M. S., Hamzah A. A., Kamarudin S. K., Abdullah J., 2009. Electrical Resistance Tomography Investigation of gas dispersion in gas-liquid mixing in an agitated vessel. J ournal of applied sciences 9(17), 3110-3115.

43. Tap water conductivity: http://www.eco-web.com/edi/111219.html

44. Tap water conductivity

http://wqaa.gov.in/WriteReadData/UserFiles/Documents/WaterQualityStandards.pdf 
45. Veera, P., Patwardhan A. W., Joshi J. B., 2001. Measurement of Gas Hold-up Profiles in Stirred Tank Reactors by Gamma Ray Attenuation Technique. Chemical Engineering Research and Design 79(6), 684-688.

46. Wang, Mao, Z.S., Yang, C., 2006. Experimental and numerical investigation on gas holdup and flooding in an aerated stirred tank with Rushton impeller. Industrial \& Engineering Chemistry Research 45, 1141-1151.

47. Wang, M., Dorward, A., Vlaev D., Mann R., 2000. Measurements of gas-liquid mixing in a stirred vessel using electrical resistance tomography (ERT). Chemical Engineering J ournal 77(1-2), 93-98.

48. Yawalkar, A. A., Pangarkar V. G., Beenackers A. A. C. M., 2002. Gas hold-up in stirred tank reactors. Canadian J ournal of Chemical Engineering 80(1), 158-166.

49. Zhang, Y. and Chen Y., 2012. A Novel PCA-GRNN Flow Pattern Identification Algorithm for Electrical Resistance Tomography System. Advances in Computer Science and Information Engineering. D. J in and S. Lin, Springer Berlin Heidelberg. $168,249-254$. 